\title{
Tectono-stratigraphy of the Çankırı Basin: Late Cretaceous to early Miocene evolution of the Neotethyan Suture Zone in Turkey
}

\author{
NURETDIN KAYMAKCI ${ }^{1 *}$, YAKUP ÖZÇELIK ${ }^{2}$, STANLEY H. WHITE $^{3} \&$ \\ PAUL M. VAN DIJK ${ }^{4}$ \\ ${ }^{1}$ Middle East Technical University, Department of Geological Engineering, 06531-Ankara \\ Turkey; Current address: Utrecht University, Forth Hoofddik Paleomag Lab. \\ Budapestlaan 17, 3584 CD Utrecht, The Netherlands \\ ${ }^{2}$ Turkish International Petroleum Company, Sögütözü Cad. No: 27, \\ 06520-Sögütözü/ANKARA, Turkey \\ ${ }^{3}$ Faculty of Geosciences, Budapestlaan 43584 CD Utrecht, The Netherlands \\ ${ }^{4}$ ITC, Hengelosestraat 99, 7514 AE Enschede, The Netherlands \\ *Corresponding author (e-mail: kaymakci@metu.edu.tr)
}

\begin{abstract}
The Çankırı Basin straddles the İzmir-Ankara-Erzincan Suture Zone which demarcates the former position of the northern branch of the Neotethys. It includes more than $3 \mathrm{~km}$ of pre-Middle Miocene in-fill related to late Cretaceous to pre-Middle Miocene evolution of the region. The basin has developed on the upper Cretaceous subduction complex and arc related basins of the Neotethys Ocean. The basin fill includes an upper Cretaceous forearc sequence overlain by Paleocene with a local unconformity. The upper Cretaceous configuration of the Çankırı basin is interpreted as a part of a forearc basin. The Paleocene and younger history is interpreted as a foreland sequence dominated by progressively southwards migrated depocenters in front of southward migrating thrust faults upon which a series of piggy-back basins were developed. Termination of the forearc setting and beginning of foreland basin conditions indicates complete subduction of the Neotethyan oceanic crust and onset of collision between the Pontides (Laurasia) and the Taurides (Gondwana) in the Paleocene. Thrusting and related sedimentation continued until the Aquitanian (Early Miocene).
\end{abstract}

The İzmir-Ankara-Erzincan Suture Zone (IAESZ; Ketin 1966) demarcates the former position of the Northern Neotethys Ocean (Şengör \& Yilmaz 1981) along which the Sakarya Continent in the north, and the Anatolide-Tauride block (in the study region represented by the Kirşehir Block, or the Central Anatolian Crystalline Complex; Fig. 1) collided. The subduction history, commencement age and collision history are still under debate.

Along the İzmir Ankara Zone, and to its south, there are two distinct ophiolitic units. The ophiolites exposed in the southern margin of the Çankırı Basin and on the Kırşehir Block are intruded by various upper Cretaceous to lower Cenozoic granitic plutons belonging to various tectono-magmatic settings (Erler \& Bayhan 1995; Boztuğ \& Jonckhere 2007; Boztuğ et al. 2007; Ilbeyli et al. 2004). Most of the ophiolites do not contain pillow lavas and have NMORB to supra-subduction zone geochemical signatures (Yalınız \& Göncüoğlu 1996; Yalınız et al. 1998, 2000). The ophiolites defining the northern margin of the Çankırı Basin (north of the suture zone) generally have NMORB geochemical signatures, are not intruded by granitoids, and have a very well developed epi-ophiolitic cover and associated forearc sequence (Rojay \& Süzen 1997; Rice et al. 2006). These characteristics, in combination with time-constraints from the stratigraphy associated with the two different ophiolitic belts, suggests a multiphase closure of the Neotethys. The oldest phase is an intra-oceanic subduction along which the southern half of the Neotethys is consumed northwards and gave way to underthrusting of the Kirsehir Block that resulted in metamorphism. Underthrusting and metamorphism of the Kirşehir Block must be older than the granitic intrusions, which range in age from 90 to $57 \mathrm{Ma}$. (Güleç 1994; Erler Bayhan 1995; Boztuğ \& Jonckheere 2007; Boztuğ et al. 2007). Following underthrusting, the Kirsehir Block was exhumed possibly during the granitic intrusion history, and came close to the surface some time between 72-57 Ma (Boztuğ \& Jonckhere 2007). In the mean time the northern part of the Çankırı Basin was 


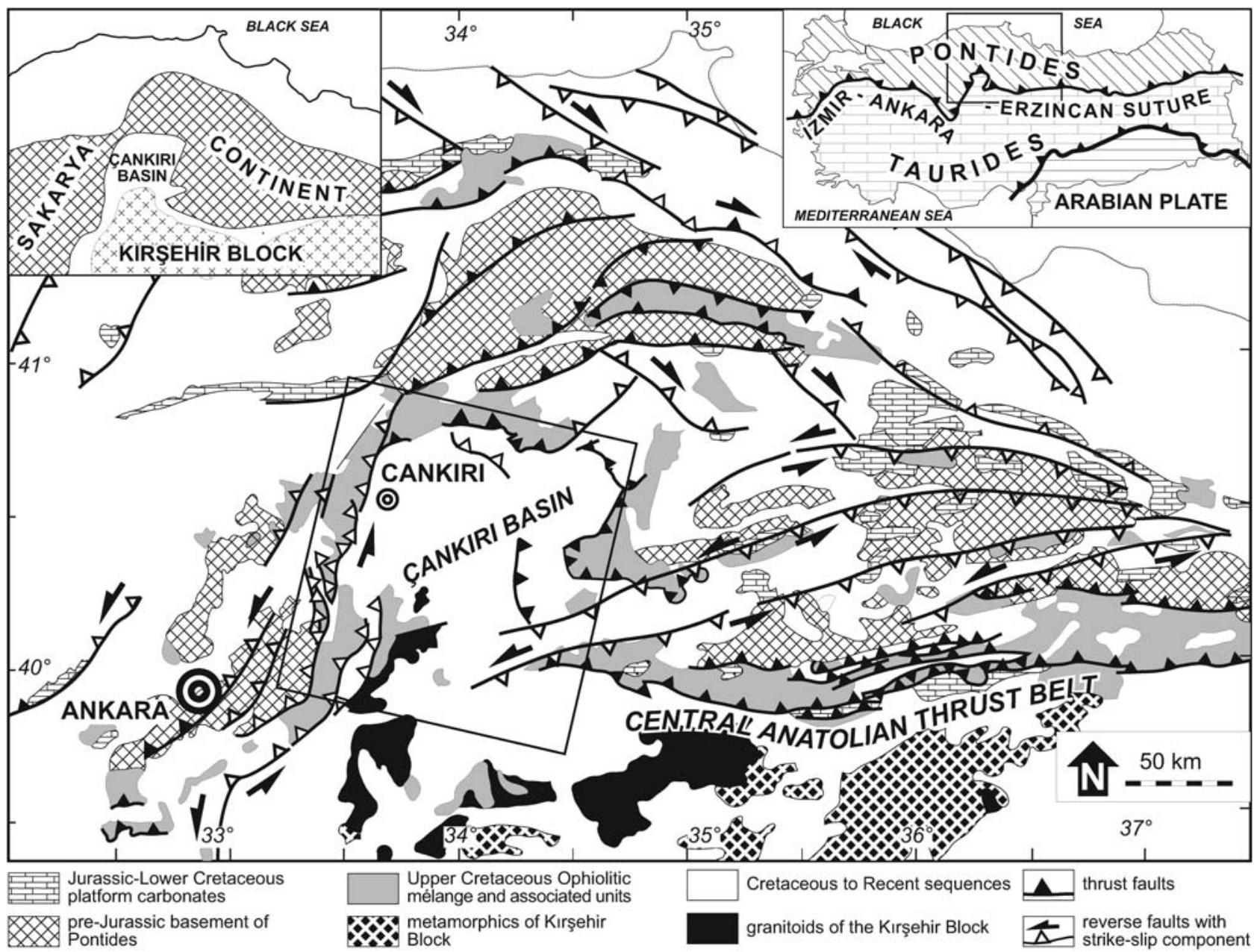

Fig. 1. Tectonostratigraphic map of Central Anatolia. Box shows the location of the Çankırı Basin. Inset maps indicate the major tectonic units in Turkey (modified from Kaymakci et al. 2000). 
closing under compressional deformation. Recent studies in the southern tip of the Kırşheir Block in Niğde Massif indicates that the exhumation of the Kırşehir Block took place in the early Cenozoic (Whitney et al. 2001; Gautier et al. 2002). Exhumation of the Kirşehir Block during compressional deformation to its northern margin raises a question whether: (1) there are two different collisional phases separated by a period of extension which exhumed the Kırşehir Block; or (2) exhumation took place during a continuous compressional deformation, due to collision, throughout the Paleocene to earliest Miocene, despite the exhumation of Kirşehir Block. In order to solve this problem, we here study the Çankırı basin, which has a continuous sedimentary history from Campanian to Miocene. Therefore, it has a sedimentary sequence that was deposited during the arc-continent collision, exhumation and final closure of the Neotethys, and may thus provide essential time constraints for the complex closurehistory of the Neotethys Ocean. Therefore, the scope of this paper is documenting the tectonostratigraphy of the Çankırı Basin in order to understand its evolution, which will, subsequently, shed light on the terminal subduction of the Neotethys, timing of collision of the Kırşehir Block and the Pontides, and events related to post-collisional convergence in the region.

\section{Geological setting}

The Çankırı Basin is located within the IzmirAnkara-Erzincan Suture Zone and is underlain by an upper Cretaceous ophiolitic mélange and granitoids of the Kirşehir Block (Figs 1,2).

The ophiolitic mélange can be considered as the subduction complex that resulted from accretion of various lithologies during the subduction of the Neotethys oceanic crust. It includes lithologies derived from both the overriding and subducting plates, together with trench deposits. It also comprises ensimatic island arc and ocean island material embedded within the ophiolitc mélange (Tüysüz et al. 1995; Rojay et al. 2001, 2004; Rice et al. 2006), which formed during the late Cretaceous. Presently, the western, northern and eastern margins of the basin are delimited by the ophiolitic mélange and the Karakaya Complex which belongs to the Sakarya Continent and are collectively called as 'rim' of the basin in an omega shape, while, in the south, it is delimited by the granitoids of the Kirşehir Block (Fig. 1).

In the southern part of the basin, there are isolated outcrops of ophiolite-related rocks which include pelagic limestones, radiolarites and sheeted dyke complexes (Fig. 2), intruded by the granitoids (e.g. Sulakyurt Granitoid) of the Kirşehir
Block. Briefly, the basin is floored by the NAOM and the Sulakyurt Granitoid; therefore, they are designated as the basement of the Çankırı Basin in this study.

\section{Stratigraphy}

In the Çankırı Basin two depositional sequences are exposed. These sequences are separated from each other with a local unconformity. Stratigraphically, there is no major depositional break between the upper Cretaceous and the Cenozoic units of the Çankırı Basin, despite the fact that the lower to middle Paleocene is missing in its southwestern and eastern margins. In the northwestern and northern parts of the basin, however, local unconformities are very common, the upper Cretaceous and Cenozoic units can be regarded as stratigraphically conformable as biostratigraphically no hiatus can be demonstrated between these sequences (Fig. 3).

\section{Basement}

\section{North Anatolian Ophiolitic Mélange (NAOM, upper Cretaceous)}

Northern central Anatolia is dominated by a number of ophiolitic belts with various rock constituents. Previous researchers named these ophiolitic units based on their present day geographic locations, the rock constituents and inferred oceanic domain of their origin. Rojay $(1993,1995)$ proposed a generalized and descriptive nomenclature for all of the ophiolite bearing units in north-central Anatolia without consideration of local constituent lithologies, age and inferred tectonic setting. For simplicity, the nomenclature of Rojay (1995) is adopted in this study.

The NAOM is exposed along all the margins of the Çankırı Basin including the southern margin where it is intruded by the Sulakyurt granitoid and exposed as patchy outcrops overlying the metamorphic continental basement rocks of the Kirsehir Block (see Fig. 2). In the central part of the basin, the NOAM is encountered in an exploration well at a depth of $3566 \mathrm{~m}$ (Topuzsaray-I, Fig. 2). Therefore, it is underlying most of the Çankırı Basin. Boundary relationships of the NAOM with other units of the Çankırı Basin are summarized in Figure 4.

Lithologically, the NAOM is composed of a tectonic mixture mainly of spilites, pillow lavas, diabase dykes, red to purple radiolarian chert, cherty limestone, reddish pelagic mudstone and various serpentinized ultramafic rocks including peridotites, harzburgites and pyroxenites. The NAOM also includes layered gabbros, plagiogranites and various limestones derived from nearby 


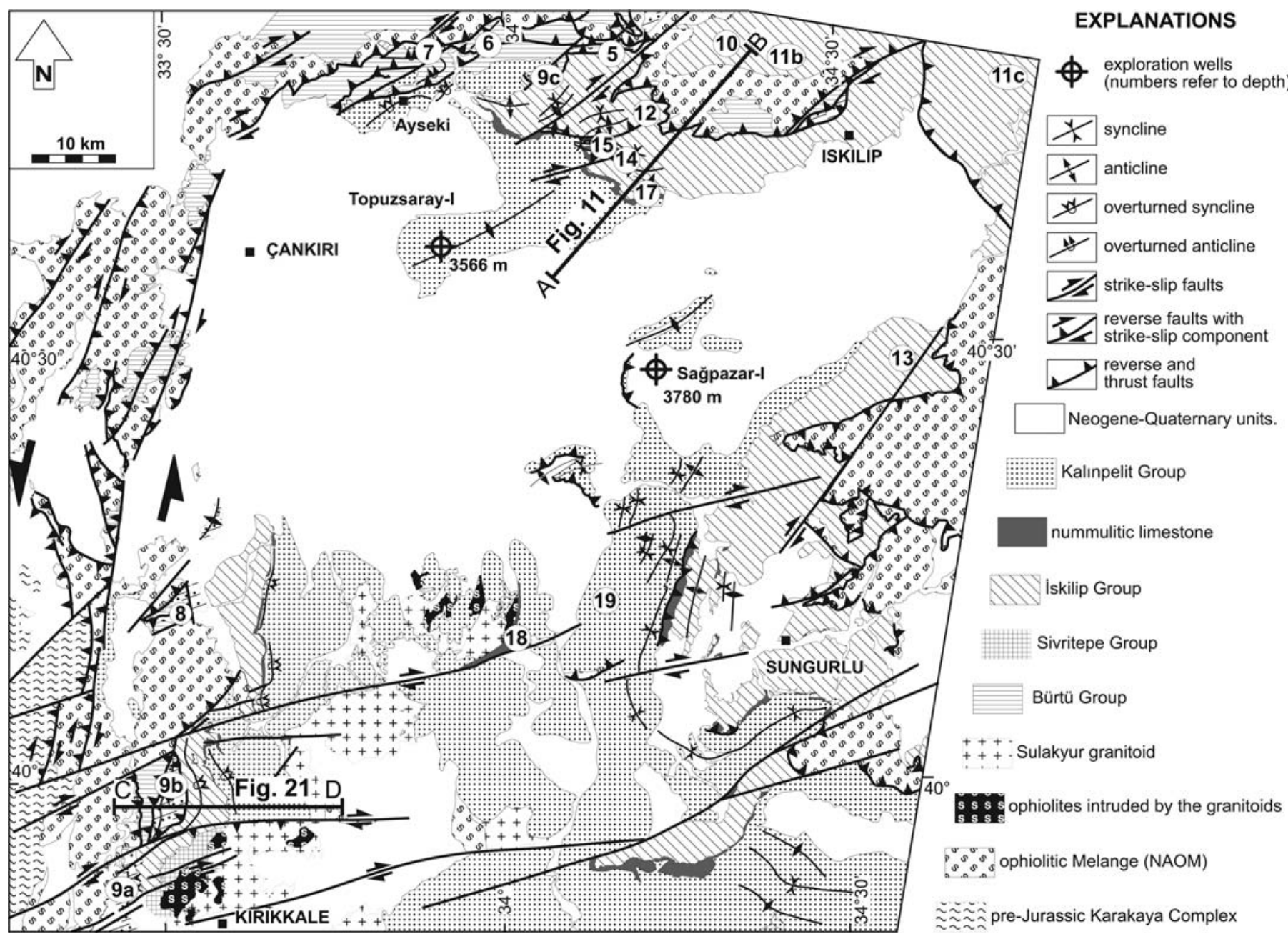

ig. 2. Geological map of the Çankırı Basin. The numbers in circles refer to the figure numbers of the measured sections. 


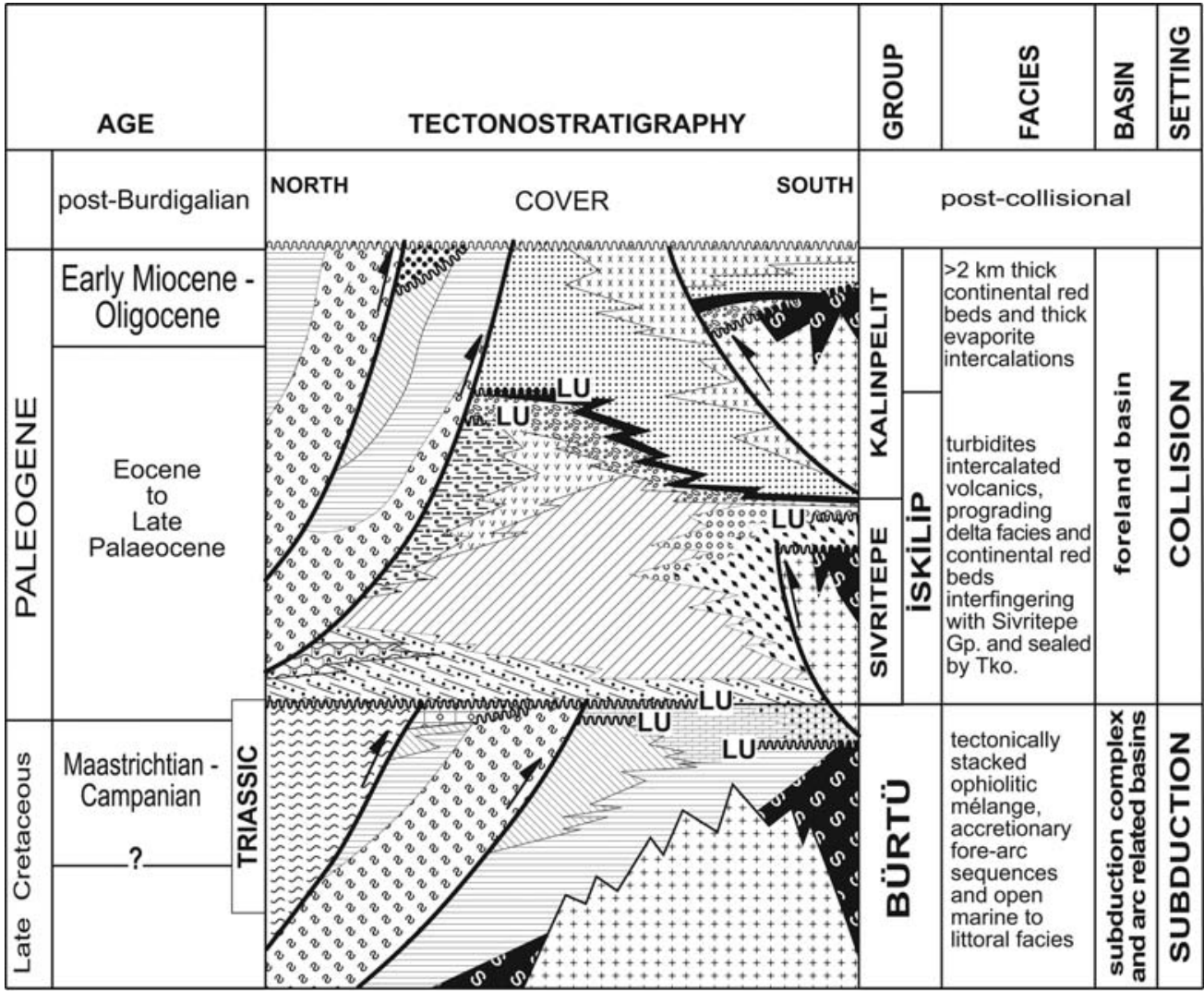

MAINLY NORTH DERIVED

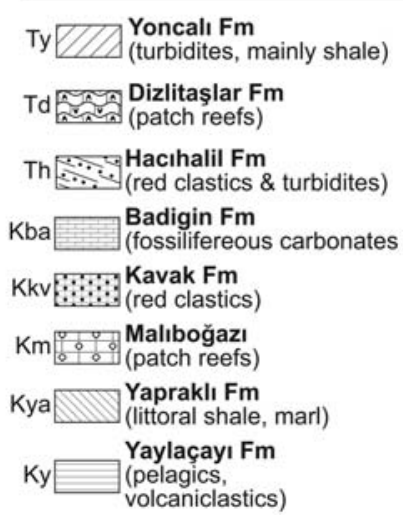

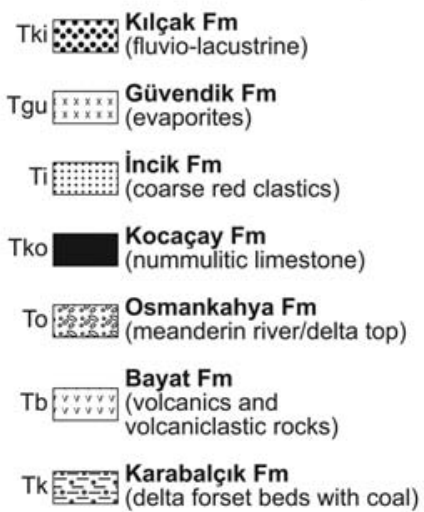

MAINLY SOUTH DERIVED

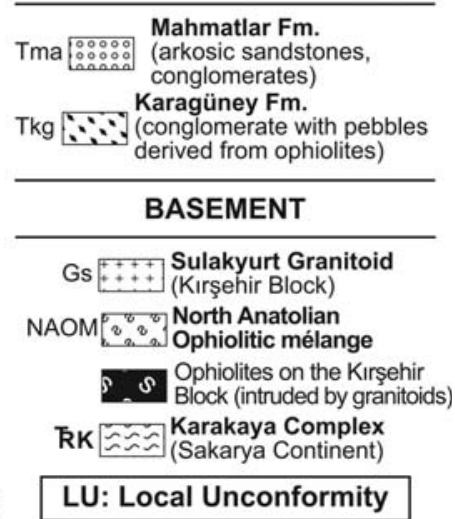

Fig. 3. Generalized tectonostratigraphic column of the units exposed in and around the Çankırı Basin.

platforms during accretion (Dellaloğlu et al. 1992; Tüysüz et al. 1995; Rojay \& Süzen 1997, Rice et al. 2006). However, the upper Cretaceous fore-arc deposits (Rice et al. 2006) are locally incorporated into the development of the NAOM and locally constitute its matrix. In general, the matrix of the NAOM is missing in most areas (Rojay
1995). Dellaloğlu et al. (1992) concluded that NAOM represents a complete ophiolitic sequence, supposedly originated from the northern Neotethys Ocean (Tüysüz et al. 1995). Variations occur geographically and the most complete sequence occurs in the western and northern rim of the Çankırı Basin. 


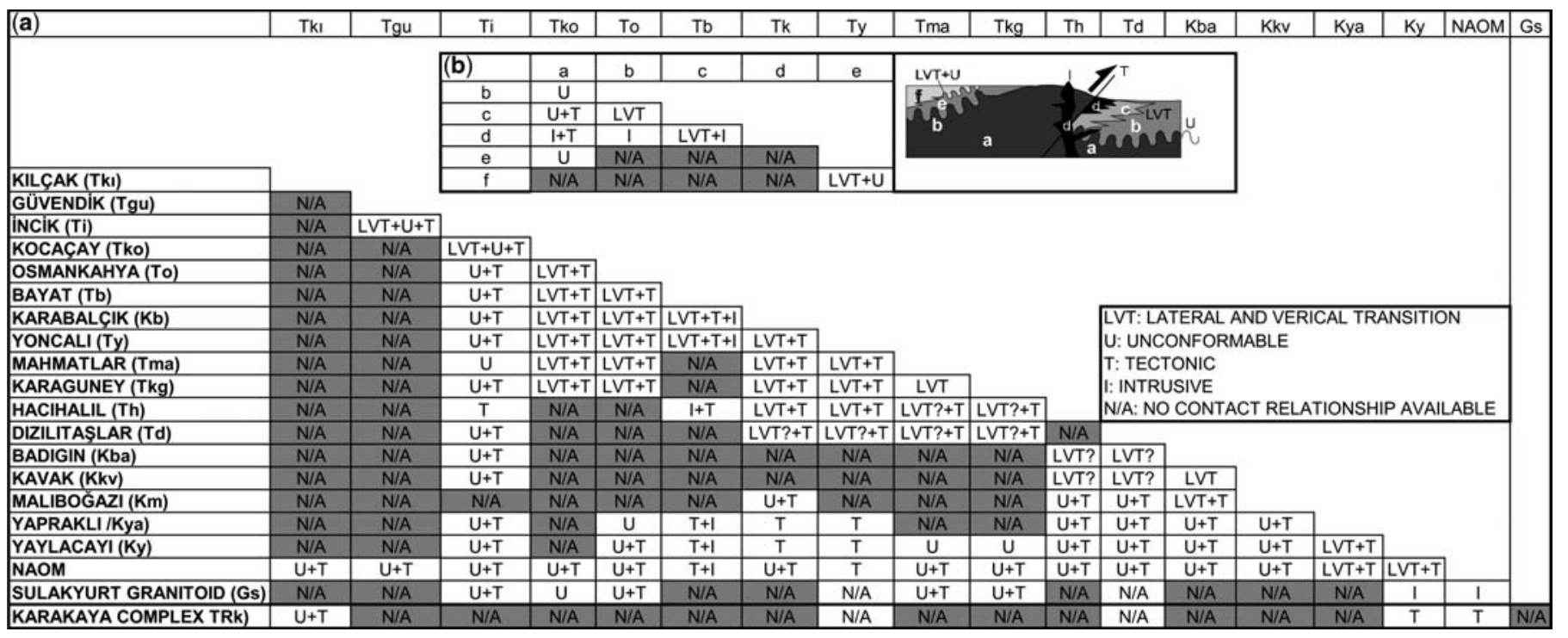

Fig. 4. (a) Contact relationships between the pre-Middle Miocene units. (b) Conceptual cross-section to explain various contact relationships observed in the Çankırı Basin. 
The main difference between the NAOM exposed along the rim and the ophiolitic units intruded by the Sulakyurt granitoid is that the ophiolitic units intruded by the Sulakyurt granitoid lack a melange character and are characterized by a greater abundance of mafic volcanic rocks, gabbros, plagiogranites, various dykes displaying dyke-in-dyke characteristics, dykes with a singe chilled margins and epi-ophiolitic deposits including radiolarites. They are also less deformed compared to the northern ones. These characteristics indicate that the southern ophiolitic units were emplaced as an intact ophiolitic slab and later intruded by the Sulakyurt granitoid, while the northern ones were incorporated into the accretionary wedge of the subducting northern Neotethys. The ophiolites intruded by the Sulakyurt granitoid in the southern margin of the Çankırı Basin have chemical signatures ranging from N-MORB to P-MORB to immature island arc settings contrary to the supra-subduction zone ophiolites exposed further south on the Kirșehir Block (Yalınız \& Göncüoğlu 1998; Yalınız et al. 1996, 2000). This relationship implies that there are two different tectono-magmatic origins of ophiolitic units on the Kırşehir Block.

\section{Sulakyurt granitoid (pre-late Paleocene)}

The geochemical characteristics of the Sulakyurt granitoid vary depending on the wall-rock properties, indicating assimilation of the wall rock. It is composed of intensely altered micro-phanaritic to phanaritic hornblende granite, granodiorite, diorite, syenite, and monzonite (Norman 1972; Akıman et al. 1993; Erler \& Bayhan 1995; Kuşcu 1997). It also includes various felsic dykes ranging from aplite to vitric rhyolite. The grain size decreases outwards from the pluton interior and is associated with 'chilled margins' and contact metamorphism (Norman 1972). It has not been isotopically dated, however, an indirect pre-late Paleocene age is indicated by the clasts of the granitoid observed within overlying upper Paleocene to middle Eocene units. In the southwestern part of the Çankırı Basin, north of Kirıkkale, the Sulakyurt granitoid intrudes the ophiolitic mélange and associated CampanianMaastrichtian units (Fig. 1).

Radiometric data from other granitoids of the Kırșehir Block are rather scarce. The radiometric ages of the known granitoids range between $110 \pm 14 \mathrm{Ma}$ based on whole rock $\mathrm{Rb}-\mathrm{Sr}$ isotopes (Güleç 1994) and $54 \mathrm{Ma}$ in the western margin of the Kirsehir block using the total $\mathrm{Pb}$ method (Ayan 1969). Boztug et al. (2007) proposed that the granitoids were emplaced during the late Cretaceous, between $94.9 \pm 3.4$ to $74.9 \pm 3.8 \mathrm{Ma}$ based on ${ }^{207} \mathrm{~Pb}-{ }^{206} \mathrm{~Pb}$ single zircon evaporation ages. They suggest that these granites are related to arc-continent collision of the Kırşehir Block with the northern Neotethyan oceanic plate. Based on fission track data, Boztuğ \& Jonckheere (2007) proposed that the granitoids exposed in the NW part of the Kırşehir Block were exhumed close to the surface around 62-57 Ma. Based on stratigraphic data, Erler \& Bayhan (1995) proposed that most of the granitoids within the Kırşehir Block were exposed prior to Eocene which indicates that the Kırşehir Block consolidated during the development of the Çankırı Basin.

In the Çankırı Basin, the oldest facies in direct contact with the Kırşehir Block is observed only in the southwestern part where generally Kırșehir Block-derived clastics dominate. The age of these deposits is late Paleocene to Eocene and indicates that the granites were exposed before the earliest Eocene, which is consistent with the radiometric data.

\section{Basin sequences}

\section{Upper Cretaceous units}

The upper Cretaceous units are deposited in a wider basin beyond the Cenozoic configuration of the Çankırı Basin and are developed on and associated with the underlying NAOM). Partly, the upper Cretaceous units including the ophiolitic mélange formed by the Yaylaçayı and Yapraklı formations were previously described by Dellaloğlu et al. (1992) as the Kalecik Group. In this study, two different formations of the Kalecik Group are recognized and named for the first time. These include Kavak and Badiğin formations (Fig. 3).

The lower part of this group (Yaylaçayi and Yaprakl1 formations) was previously interpreted to be associated with accretionary wedge (subduction complex) growth and development of a magmatic arc and arc related basins during the northwards subduction of the Tethys in the late Cretaceous (Tüysüz et al. 1995; Kaymakc1 2000; Rice et al. 2006).

\section{Bürtü group}

The Bürtii group comprises upper Cretaceous to Paleocene units. These include Yaylaçayı, Yapraklı, Malıboğazı, Kavak and Badiğin formations.

Yaylaçayı Formation (Ky, Campanian to Maastrichtian). The Yaylaçayı Formation was first named by Yoldaş (1982). It consists mainly of a volcano-sedimentary sequence (Fig. 5), is exposed at the rim of the Çankırı Basin and is associated with the NAOM. It is regarded as a distinct formation because locally it can be mapped as a separate unit and its internal structure is preserved. Lithologically, the Yaylaçayı Formation exhibits very abrupt lateral facies change. The 


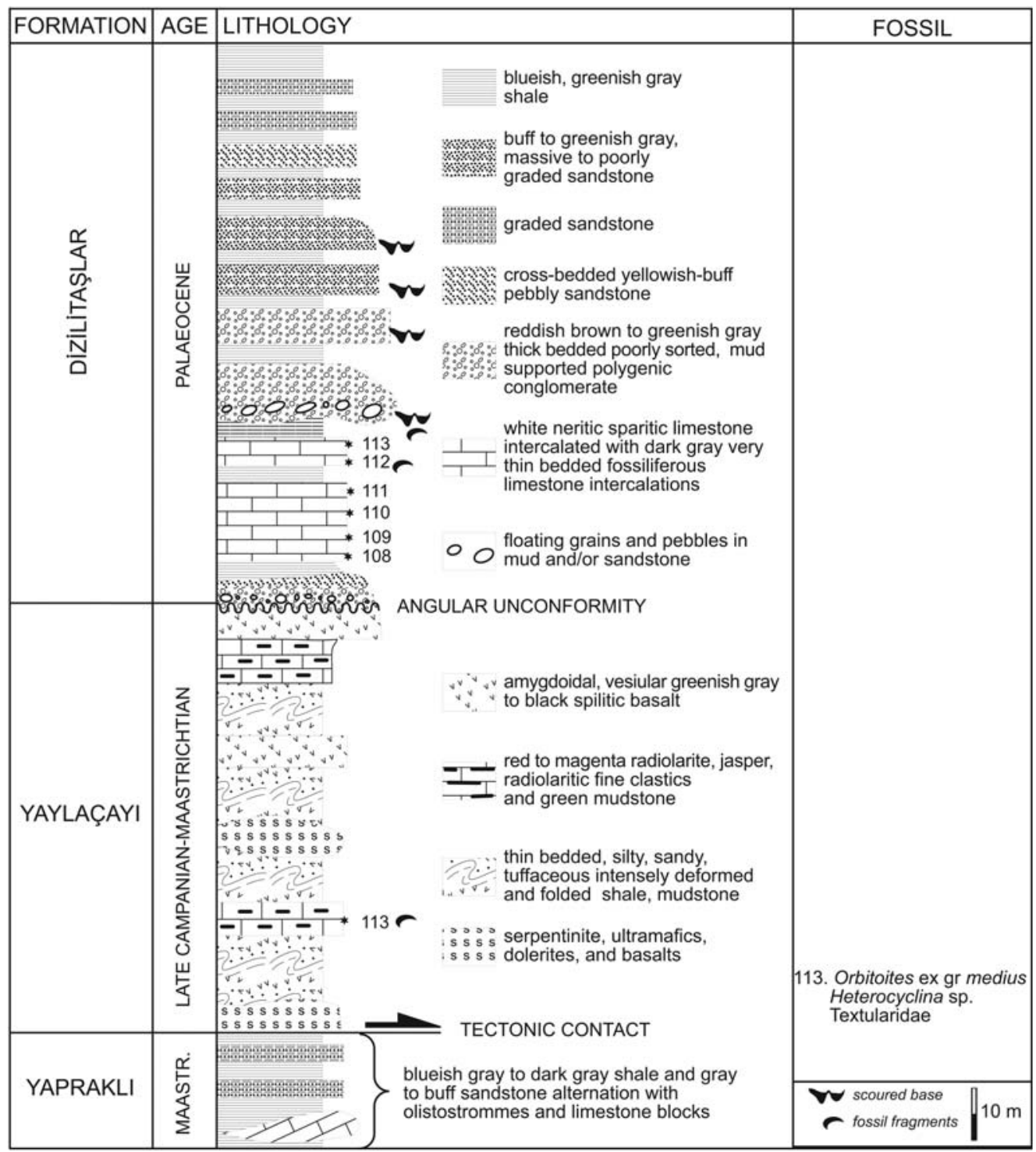

Fig. 5. Measured stratigraphical section for parts of the Yaylaçayı and Dizilitaşlar Formations (its location is indicated with 5 in Fig. 2).

bottom of the formation is well exposed at the southwestern part of the Çankırı Basin NW of Kırıkkale (Fig. 2). The dominant character of the unit is the presence of various volcanogenic horizons in which basalts, tuffs and tuffites are intercalated with shales and pelagic marly limestones. In general, it is composed of three distinct lithological associations. From bottom to top these are: (1) red to purple marl, marly pelagic limestone, volcanogenic sandstone, and tuff alternations; (2) pelagic fauna bearing micritic limestone and green shale alternation, intercalated with alternations of spilitic olistostromes and tuff; and (3) turbiditic sandstone and shale alternations intercalated with tuff, agglomerate, beige silty argillaceous limestone, and marl grading upward into a benthic fossil bearing sandy limestone (Fig. 6). Being deposited on top of the ophiolitic mélange and overlain by upper Cretaceous regressive terrigeneous deposits, the Yaylaçayi Formation is inferred to be deposited in a forearc setting (Rojay \& Süzen 1997). Tüysüz et al. (1995) argue that the Yaylaçayı Formation 


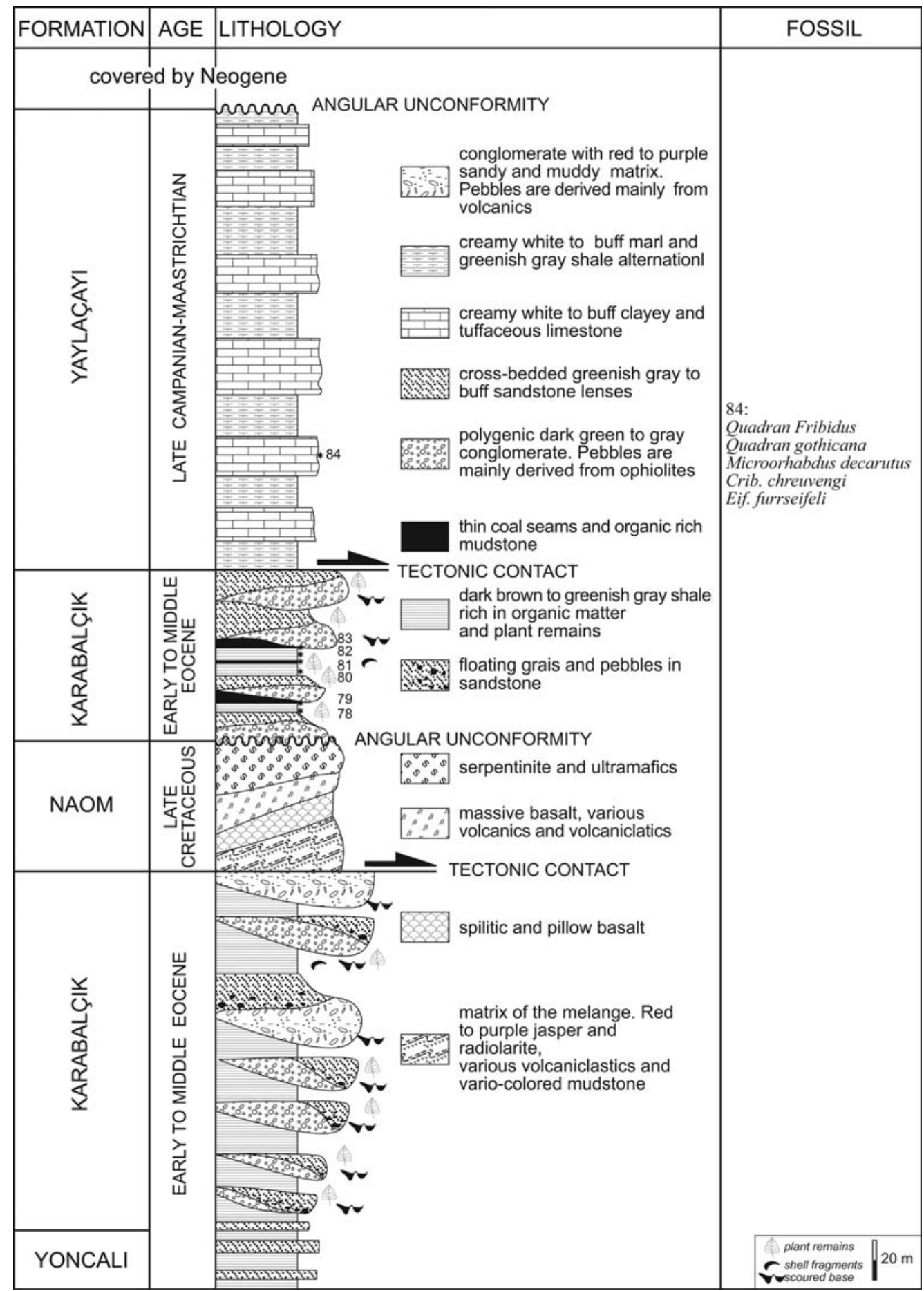

Fig. 6. Measured stratigraphical section for a part of the Yaylaçayı and Karabalçık Formations (its location is indicated with 6 in Fig. 2). 
represents an intra-oceanic setting due to the lack of terrigenous material (see also Rice et al. 2006).

The age of the unit varies from Maastrichtian (Yoldaş 1982), Cenomanian-Campanian (9971.3) Ma (Akyürek et al. 1984), to SantonianCampanian (85.8-71.3 Ma) (Tüysüz 1985; Dellaloğlu et al. 1992), and Cenomanian-Late Maastrichtian (99-65 Ma) (Tüysüz et al. 1995). The following foraminifera fauna have been identified at the base of the Yaylaçay1 Formation: Orbitoides ex gr medius, Heterocyclina sp., Textularidae (Fig. 5) and from the upper part of the formation following nannofossils have been identified: Quadran fribidus, Quadran gothicana, Microrhabdus, decarutus, crib. chreuvengi, Eif. furrseifeli, which are of late Campanian to Maastrichtian age (Fig. 6). Considering these ages and those of the above fauna, it is concluded that the Yaylaçayı Formation was deposited in the Santonian to Maastrichtian interval. This time interval corresponds also the onset of volcanic arc development (Yemişliçay Formation, Görür 1997) in the central Pontides north of the Çankırı Basin.

Yapraklı Formation (Kya, Campanian-Paleocene). The Yapraklı Formation was first named by Birgili et al. (1974). It is characterized by limestones with macrofossils and fine-grained clastics. The Yaprakl1 Formation (see Figs 6-8) displays local coarsening-upward sequences and bears evidence for progressive shallowing of the depositional environment, indicated by the transition from fine clastics to neritic limestones. The bottom of the formation is composed of explosive volcanic rocks such as white tuff and agglomerate intercalations. In the middle, it is characterized by turbiditic macrofossil bearing, volcanoclastic conglomerate, sandstone and multicolored shale. Towards the top, limy units and fossiliferous limestones are present. Locally, the unit includes olistostromal horizons. In addition, the unit also includes thick-shelled pelecypoda, wood and plant remains especially in its upper parts, which indicates close proximity to the margin of the basin.

Dellaloğlu et al. (1992) have proposed a Senonian to Maastrichtian age for this formation based on planktonic foraminifera, gastropoda and pelecypoda fossils. However, the fossils identified in this study yielded Maastrichtian to Paleocene age in the Malıbogazı section (Fig. 8) and Maastrichtian in Kağnıkonağı section (Fig. 6), and Campanian to Maastrichtian in the Badiğin section (Fig. 7). This age range indicates that the Yapraklı Formation was deposited diachronically in the Campanian(?) to Paleocene interval.

Because the Yapraklı Formation conformably overlies and laterally grades into the Yayalaçayı Formation, we interpret it as partly the proximal equivalent of the Yaylaçayı Formation.
Malıboğazı Formation (Km, upper CretaceousPaleocene). The Malıboğazı Formation was previously named by Ayan (1969). It is exposed only in the central southwestern part of the Çankırı Basin. In the Topuzsaray-I well, it is encountered at depths between 2907 to $3090 \mathrm{~m}$. The Malıboğazı Formation comprises approximately $200 \mathrm{~m}$ of condensed neritic reefal limestones with rich Rudist, Exogyra, and Orbitoides (Figs 7 \& 8) interlayered with spilitic basalts and volcaniclastics. It is conformably deposited on the NAOM as isolated patchy reefs. Similar facies are also reported from elsewhere outside of the Çankırı Basin (see Ünalan 1982; Bingöl 1984; Yazgan 1984; Rojay \& Süzen 1997).

Kavak Formation (Kkv, upper CretaceousPaleocene). The Kavak formation is informally named in this study. It is exposed only in limited outcrops in the northwestern part of the basin and also encountered in the Topuzsaray-I well at a depth of $3090 \mathrm{~m}$, and is around $150 \mathrm{~m}$ thick.

The Kavak formation comprises approximately $15 \mathrm{~m}$ of polygenic conglomerates with a limy matrix overlain by a very thickly bedded red to purple conglomerate and sandstone alternation. It laterally grades and overlies the Yaprakl1 Formation with local unconformities. It includes reworked upper Cretaceous fauna and detritus derived mainly from the basement metamorphic rocks, NAOM, Yaylaçayı and Yapraklı formations (Fig. 7).

Badiğin Formations (Kba, upper CretaceousPaleocene). The Badiğin formation is exposed in the northwestern corner of the Çankırı Basin. It is composed of 100 to $200 \mathrm{~m}$ thick buff to yellow marl containing gastropoda, exeogyra, worm tracks and pelecypoda fragments and a very thick fossilifereous sandy limestone with intercalations of red sandstone containing fossil fragments and limestone concretions, and of calcite cemented conglomerate (Figs 7 \& 8 ). Like the Kavak formation, it laterally grades into and and overlies the Yaprakl1 Formation with a local unconformity. It was deposited in near-shore to neritic environments in the latest Maastrichtian to Paleocene.

\section{Cenozoic units}

The Cenozoic infill of the Çankırı Basin displays an asymmetrical wedge-like geometry being thicker in the west, north and the east, where it is overthrusted by the northern ophiolites, and become thinner towards the south where it is onlapping onto the Kırşehir Block. The oldest and the thickest deposits lie near the thrust margin and are generally structurally imbricated due to compressional deformation. 


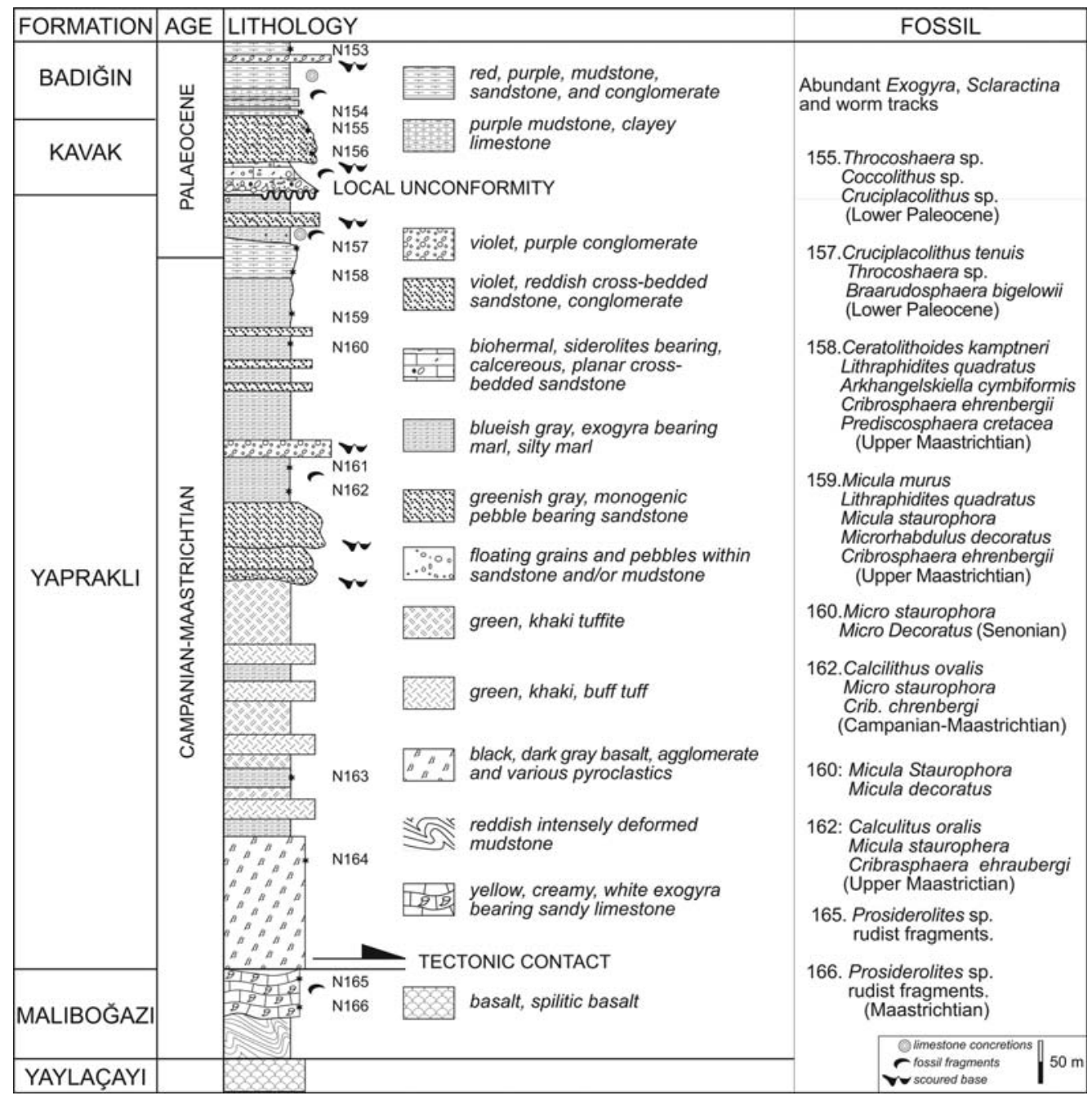

Fig. 7. Measured stratigraphical section for a part of the Yapraklı Formation (its location is indicated with 8 in Fig. 2).

They constitute sedimentologically a proximal facies, which markedly become thinner towards the basin centre. Some of these facies (Karagüney, Mahmatlar, Kocaçay and Incik Formations) progressively onlap on to the Kurşehir Block in the south. Such geometry combined with sedimentological and structural observations will be discussed in the forthcoming sections.

As mentioned above, the basin is structurally delimited along the rim by south-vergent thrust faults which are displaced by multidirectional normal faults of middle Miocene age and later by NE-SE oriented strike-slip faults which developed since the late Miocene. Renewed compression during the post-middle Miocene resulted in coaxial deformation which complicates the lower Cenozoic structures (Kaymakc1 et al. 2000; 2001b; 2003a \& b).
The Cenozoic infill of the Çankırı Basin received detritus mainly from two different sources. The main groups which cover all but the southwestern corner of the basin are devoid of pebbles derived from the granitoids of the Kırşehir Block and their thickness and grain sizes consistently decrease from the rim to the basin center towards the southern margin. Therefore they are described here as the north derived units (see also palaeocurrent data of Norman 1972). On the other hand, the units in direct contact with the Kırşehir Block, along the southern margin of the basin, shed detritus from the granitoids as indicated by granitic pebbles and arkosic sandstones. Therefore, they are categorized here as south derived units. 


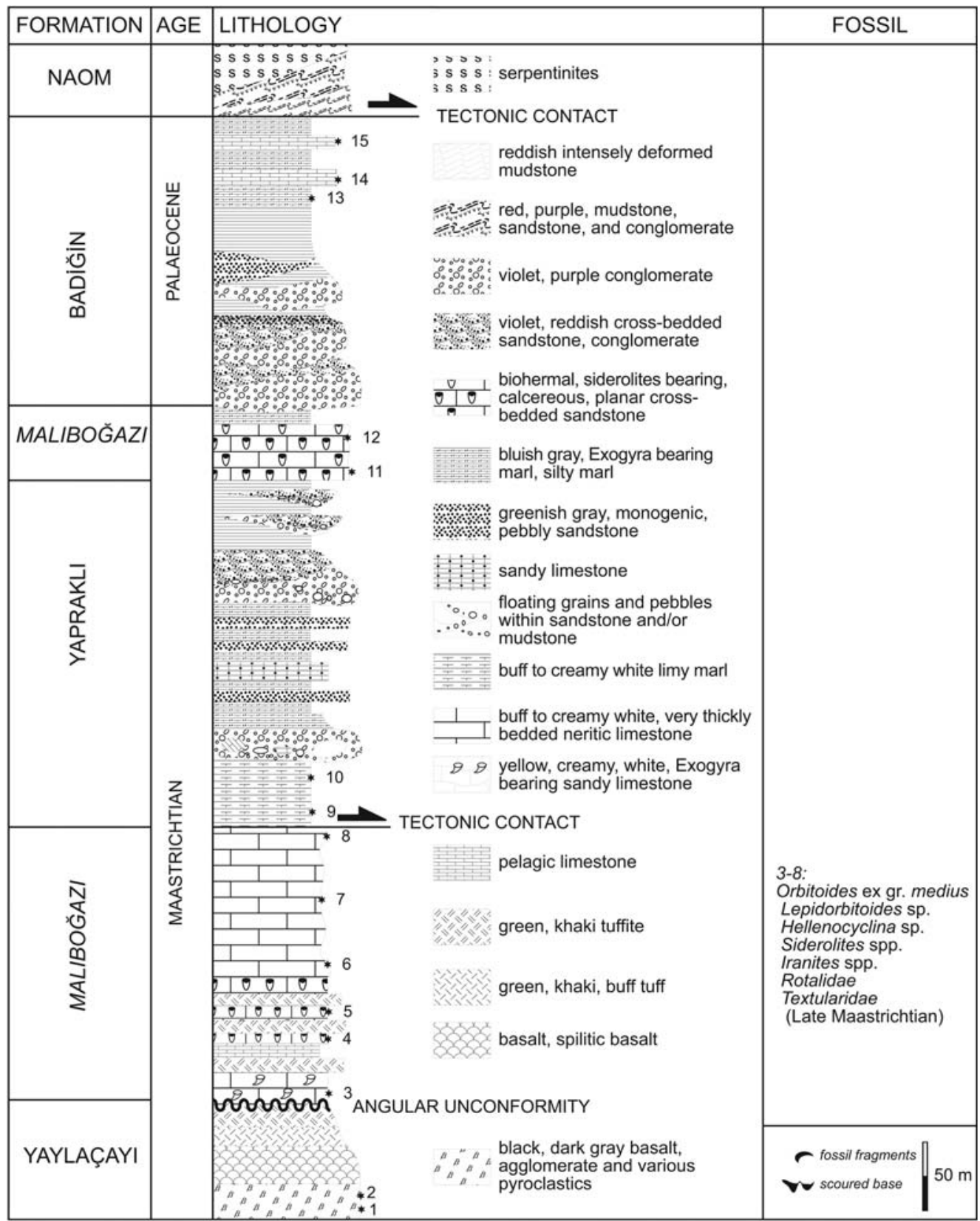

Fig. 8. Measured stratigraphical section for a part of the Malıboğazı, Yapraklı and Badiğin formations (its location is indicated with 8 in Fig. 2).

\section{North derived units}

The north derived facies developed in front of the rim and constitute the upper Paleocene to middle Eocene marine flysch to continental molasse successions (Hacıhalil, Dizilitaşlar, Yoncalı, Karabalçık formations), and are associated with middle Eocene volcanic rocks (Bayat Formation) covered by continental red clastics and a nummulitic condensed sequences of middle Eocene age (Osmankahya and Kocaçay formations respectively). Kocaçay Formation is a key horizon in the Çankırı Basin, which 
together with the Osmankahya Formation, covers both the older basin units and the Kırşehir Block and is the youngest marine deposit within the Çankırı Basin. The Kalınpelit group (informally named in this study) conformably overlies the Kocaçay Formation and comprises a very thick sequence of continental red clastics and evaporites of post-middle Eocene to Oligocene and lower Miocene fluvio-lacustrine deposits. The lower Cenozoic units of the Çankırı Basin were collectively named as the Iskilip Group by Dellaloğlu et al. (1992). In this study, it is divided into two subgroups while the name 'Ískilip Group' is restricted to the lower part of the sequence and is characterized mainly by marine successions while the overlying continental units are informally named as the Kalinpelit group (Fig. 3).

Iskilip Group. The İskilip Group was first named by Dellaloğlu et al. (1992) and comprised all the lower Cenozoic deposits of the Çankırı Basin. In this study the Iskilip Group is restricted only to the upper Paleocene to middle Eocene marine successions of the Çankırı Basin. It includes the Hacıhalil, Dizilitaşlar (Fig. 9), Yoncalı, Karabalçık, Bayat, Osmankahya and Kocaçay formations.

Hacihalil Formation (Th, upper Paleocene to middle Eocene). This formation was first named by Birgili et al. (1974). It is composed of alternations of conglomerates, sandstones and shale (Fig. 10). It is exposed mainly in the southwestern, northern and north-eastern margin of the basin (Fig. 2). Its thickness ranges between 300 to $1360 \mathrm{~m}$.

The Hacihalil Fm conformably overlies the upper Cretaceous units of the northwestern part of the Çankırı Basin. In the northern part of the basin (Fig. 2), approximately $30 \mathrm{~m}$ thick conglomerates rest on the NAOM with an unconformity (Fig. 11b). The individual beds are up to $3 \mathrm{~m}$ thick, poorly sorted, generally loosely packed and matrix supported. The matrix consists of sandstones. The largest pebbles are up to $20 \mathrm{~cm}$ in diameter and are derived from the NAOM, Yaylaçayı and Yapraklı formations. They are sub-rounded to ellipsoidal, frequently displaying imbrications. The sandstones are up to $2 \mathrm{~m}$ thick and locally graded. The shales include widespread bioturbation, floating pebbles, mud-balls, plant and macro fossil fragments and widespread nummulite fossils (Fig. 10). In this area, according to the sedimentological study of Ocakoğlu \& Çiner (1997), the Hacıhalil Formation comprises 6 different facies. They are, from north to south: proximal alluvial fan, braided river, meandering river, fan delta and near shore to prodelta/open marine facies. The main sources of sediments are located to the NW, although sediments were also supplied from the SE (Ocakoğlu \& Çiner 1997).
The age of the Hacihalil Formation, as indicated by its fossil contents (Fig. 10), is upper Paleocene to middle Eocene, which has also been reported by Aziz (1975), Yoldaş (1982), Tüysüz (1985), Dellaloğlu et al. (1992).

Dizilitaşlar Formation (Td, Paleocene). The name Dizilitaşlar Formation was first used by Norman (1972) for the Paleocene flysch-like conglomerates and sandstones intercalated with neritic limestones (Fig. 9). In the southwestern part of the Çankırı Basin, it is composed of an approximately $60 \mathrm{~m}$ thick green, greenish grey medium- to thickbedded $(10-50 \mathrm{~cm})$ shale and thin-bedded $(2-$ $5 \mathrm{~cm}$ ) sandstone alternation at the bottom. This is succeeded by conglomerates, thickly bedded (1-2 m locally) sandstone and shale alternation. The conglomerate pebbles are derived from the NAOM, Yaylaçayı, Yapraklı and Malıboğazı formations and felsic magmatic rocks. The sandstones are locally cross-bedded and graded. It is overlain by an approximately $50 \mathrm{~m}$ thick shale sequence alternating with thin-bedded sandstones (Fig. 9).

The central part of the formation (Fig. 9) is constituted by an approximately $100 \mathrm{~m}$ thick, buff to dark grey neritic limestone (D3 member of Norman 1972), calcarenite and intercalated pebbly sandstone, boulder-conglomerates and shale. It also includes olistostromal horizons in which limestone blocks are set in a shaly matrix. The limy horizon is followed upwards by an alternation of medium- to thick-bedded shale and thin-bedded sandstone with a cumulative thickness of approximately $200 \mathrm{~m}$. At the western margin of the basin, the Dizilitaşlar Formation is intensely deformed and folded. At the bottom, the Dizilitaşlar Formation is characterized by conglomerates and followed upwards with neritic limestones. At the top part, it is constituted by an approximately $150 \mathrm{~m}$ thick lime-cemented sandstones and conglomerates followed upward by, approximately $150 \mathrm{~m}$ thick, graded sandstone and thin beds of shale alternation. In the northern margin of the basin, the Dizilitaşlar Formation is represented by thin sandstone-shale alternations at the bottom and a very thick massive neritic limestone followed by a thin alternation of sandstone and shale (Fig. 9).

According to Norman (1972) and Dellaloğlu et al. (1992) the age of the Dizilitaşlar Formation is Paleocene. According to Kazanc1 \& Varol (1990), the Dizilitaşlar Formation comprises a mass flow-dominated fan-delta complex (cf. Postma 1983) at the bottom and sand dominated turbidites at the top. The limestones within the Dizilitaşlar Formation were deposited in fringing patch reefs in a regressive setting. 
$\begin{array}{ll}\text { (a) SW margin } & \text { (b) } \mathrm{W} \text { margin }\end{array}$

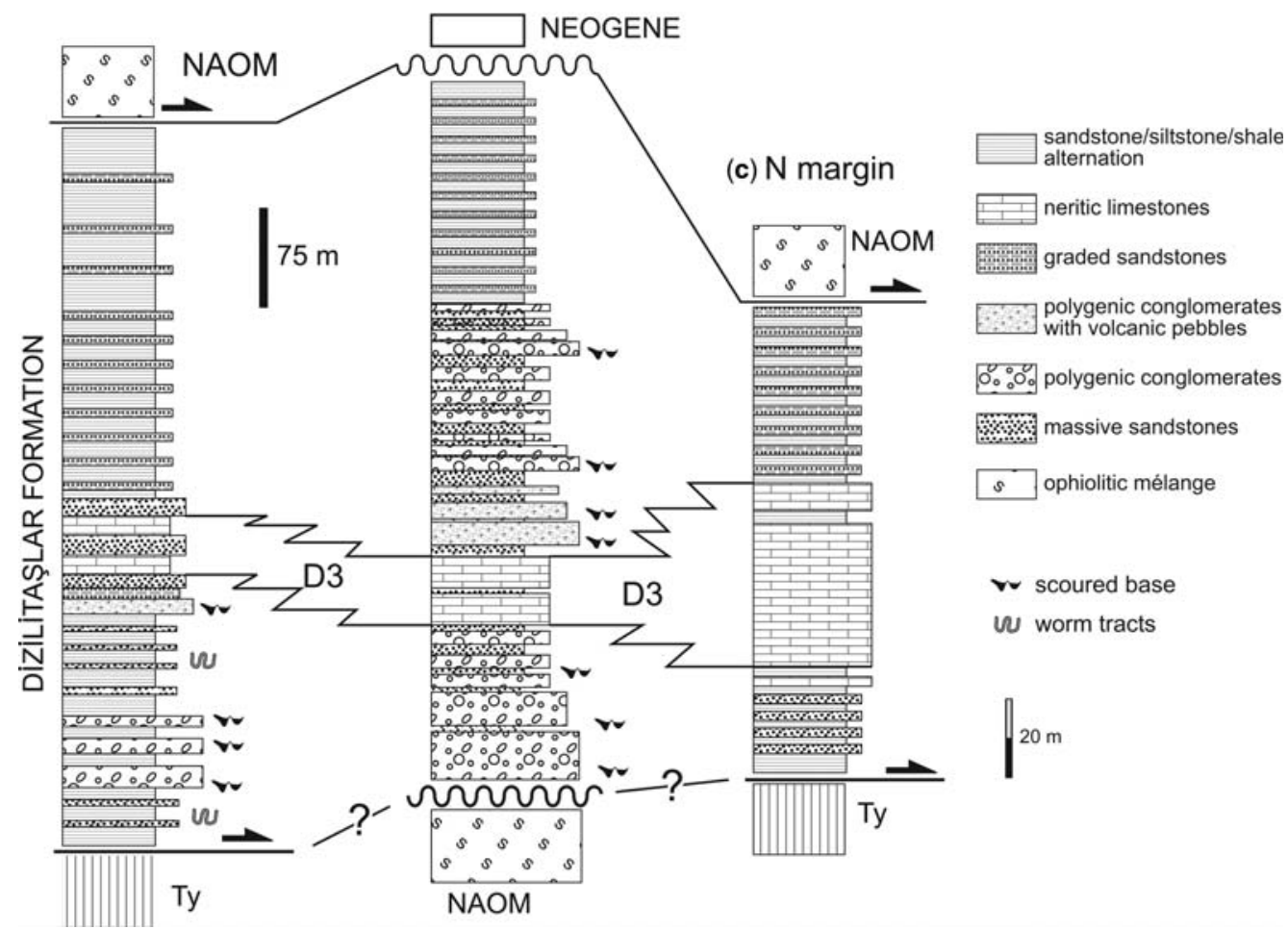

Fig. 9. Generalized columnar sections for the Dizilitaşlar Formation in the southwestern, western and northern margins of the Çankırı Basin (partly modified from Norman 1972; Dellaloğlu et al. 1992) (location of the sections are indicated with $9 \mathrm{a}-\mathrm{c}$ in Fig. 2).

Yoncalı Formation (Ty, upper Paleocene to middle Eocene). The Yoncali Formation was first named by Aziz (1973). It consists mainly of shale and sandstone alternations (Figs $12 \& 13$ ). It is always transitional at the bottom with the Hacihalil Formation and has lateral and vertical gradations to the Karabalçık, Bayat, Osmankahya and Kocaçay formations. It is unconformably overlain by the Incik and younger formations. It has tectonic boundary relationships with the NAOM and is intruded by generally WNW-ESE orientated feeder dikes of the Bayat Formation (Demirer et al. 1992). For example, in the north-eastern part of the area, the thrust contact between underlying Yoncalı Formation and overlying NAOM is intruded by the feeder dikes of the Bayat Formation (Fig. 11c). This relationship indicates compressional deformation and thrusting of the NAOM during or after the deposition of the Yoncall Formation in the upper Paleocene to middle Eocene.

In the northern part of the basin, the Yoncalı Formation is composed mainly of alternations of shale, sandstone and thin beds of conglomerate. The shales are dark green to dark grey and thin- to thick-bedded
$(10-100 \mathrm{~cm})$. The sandstones are dark green to buff, fine to medium-grained. They are graded, planar cross-bedded and current ripple-laminated at various levels. The conglomerates are made up of pebbles derived mainly from ophiolitic rocks including radiolarian chert, serpentinite, micritic limestones, basalt, and tuffs. They are subrounded to rounded and the largest clast size is around $5 \mathrm{~cm}$ in diameter. The Yoncalı Formation also comprises olistostromes containing pebbles of pelagic limestone, spilitic basalt and serpentinite blocks of various sizes (up to few tens of metres) derived from the ophiolitic units and are enclosed by dark grey shales (Figs $12 \& 13$ ).

Along the eastern margin, the Yoncalı Formation is characterized by regular alternations of sandstone, siltstone, shale, and pelagic limestone (Fig. 13). The thickness of the beds ranges between 2 and $10 \mathrm{~cm}$. In this part of the basin, the base of the Yoncalı Formation is not exposed, as it is overthrusted by the NAOM.

The age of the unit is of upper Paleocene to middle Eocene as indicated by its fossil content (Figs $12 \& 13$ ). 


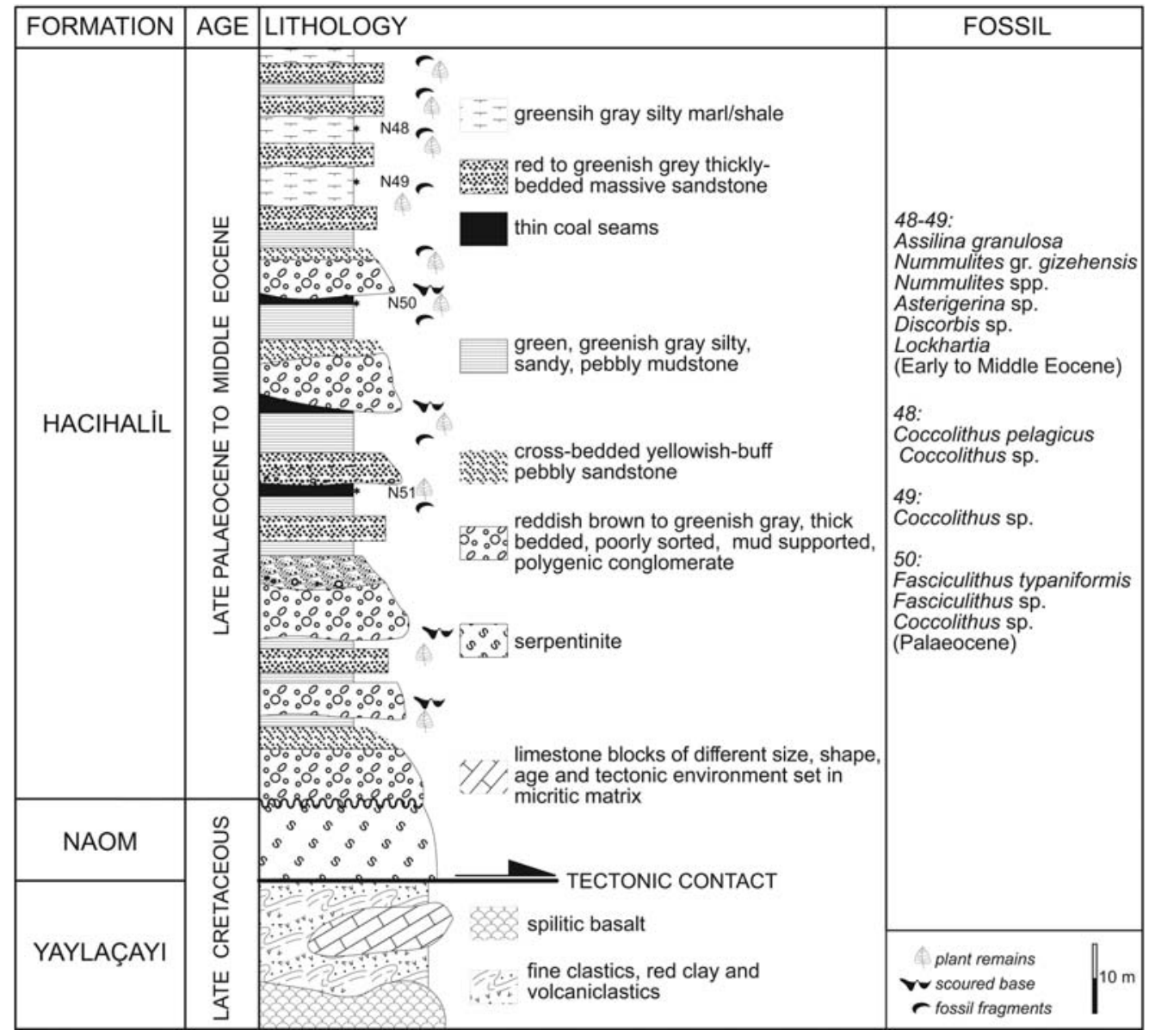

Fig. 10. Measured stratigraphical section for a part of the Hacihalil Formation (its location is indicated with 10 in Fig. 2).

Karabalçı Formation (Tk, upper Paleocene to middle Eocene). The Karabalçık Formation is named by Dellaloğlu et al. (1992) and represented mainly by conglomerates with alternating sandstones and shales and tuff/tuffite intercalations (Figs 12 \& 14). It is well developed in the western and northern parts of the basin. In the east it is either not developed or represented by the channellike patches of conglomerates within the Yoncal Formation and channel-like conglomerates unconformably resting on the NAOM. In the northern part of the basin, the Karabalçık Formation laterally grades into the Yoncalı, Bayat and Osmankahya formations.

In the northern part of the Cankırı Basin, the Karabalçık Formation is characterized by thick beds of polymict conglomerate containing subrounded to well-rounded pebbles of quartzite, mafic volcanic rocks, vitric tuff, marble, fossiliferous white limestone, micritic limestone, green schist, sandstone and radiolarian chert. These lithologies are derived from the underlying metamorphic rocks, ophiolitic units and other upper Cretaceous units. Some parts of the conglomerates are intensely oxidized and have a clayey and sandy matrix cemented by secondary calcite. Towards the top, the conglomerates are succeeded by an alternation of yellowish grey, medium- to thick-bedded sandstone, greenish grey medium- to thick-bedded shale, and orange to buff thick-bedded conglomerates. Higher up in the section, the Karabalçık Formation is composed of sandstone, siltstone and marl alternations and at least four levels of economic coal horizons (up to $2 \mathrm{~m}$ thick). Towards the top, a number of olistostrome levels and very thick $(>5 \mathrm{~m})$ cross-bedded conglomeratic sandstones dominate (Fig. 15). The top part includes intercalations of conglomerate and sandstones with fossiliferous horizons characterized 


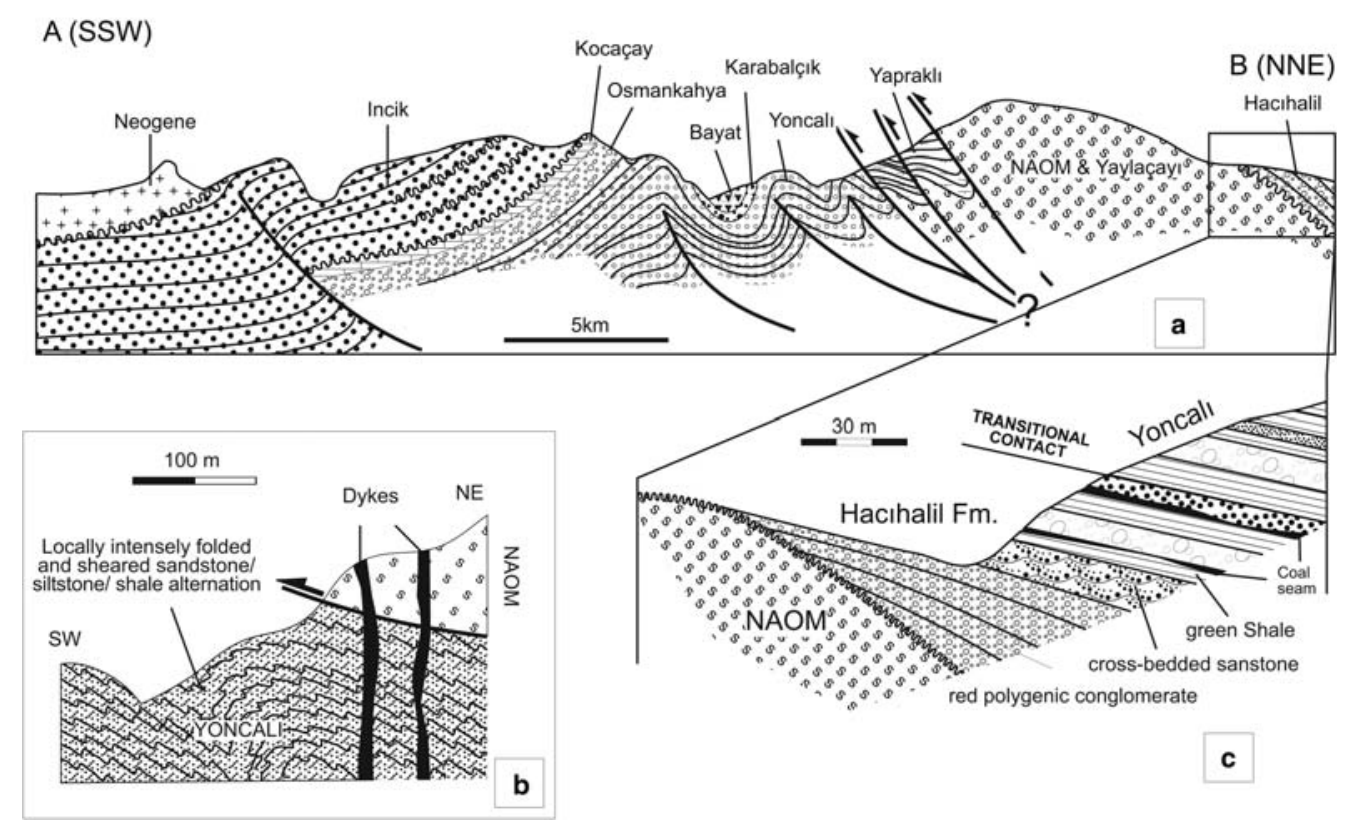

Fig. 11. (a) Schematic cross-section along line A-B in Fig. 2. (b) Schematic cross-section illustrating how the thrust contact between the North Anatolian Ophiolitic Melange (NAOM) and the Yoncalı Formation is cut by the dykes of Bayat Formation (11b in Fig. 2.) (c) Blow-up figure depicting the relation between NAOM, Hacihalil and Yoncalı formations (11c in Fig. 2).

by imbrication of transported and reworked nummulite fossils (Fig. 14). The orientation of cross beds indicates sediment transport in NW to SE direction.

In the western parts of the basin, the Karabalçık Formation displays a very well developed coarsening upwards sequence starting from the Yoncalı Formation at the bottom and grading into the Osmankahya Formation, which, in turn, grades into Kocaçay Formation that marks the youngest marine unit in the basin. The beds of conglomerates may locally reach up to $5 \mathrm{~m}$ thickness. Generally, these are loosely packed, unsorted and lack any internal sedimentary structure, but locally planar cross-bedded and graded horizons are present. The sandstones are medium- to thick-bedded. Age of the formation is early to middle Eocene as indicated by its fossil content (Figs $14 \& 17$ ).

Bayat Formation (Tb, upper Paleocene to middle Eocene). This unit was first named by Ayan (1969). It is a widespread unit in the northern and northeastern parts of the study area. It is characterized by a volcano-sedimentary sequence. Its thickness varies from about $300 \mathrm{~m}$ in the north to few meters in the eastern part of the basin and it is not developed in the southwestern part of the basin.
Locally, the Kocaçay Formation has an interfingering relationship with the Bayat Formation (Fig. 16). Lithologically, the Bayat Formation comprises two distinct parts (Figs 14, 16 \& 17). The lower part is composed of marl, sandstone, conglomerate and tuff intercalations. The marls are green to dark green, medium- to thick-bedded, generally tuffaceous, and locally contain conglomerate lenses of pebbles derived from volcanogenic material. Sandstones are yellowish green, dark grey and generally medium bedded. The grains are medium to coarse in size, sub-angular to sub-rounded and derived from mafic to intermediate volcanic rocks. They also contain wood and plant remains. The conglomerate lenses within the marls and tuffs are green to grey, medium- to thick-bedded. Pebbles are up to $10 \mathrm{~cm}$ in diameter, sub-rounded. Tuffs are green, yellowish green, thin- to medium-bedded.

The upper part of the Bayat Formation is mainly composed of various volcanic rocks intercalated with tuffaceous marls. Based on their origin and composition, the volcanic rocks of the Bayat Formation are divided into four categories (Demirer et al. 1992): (1) tholeiitic-basalts and tholeiitic-olivine basalt of mantle origin; (2) hornblende-biotite-andesite, biotite-andesite, pumicic biotite-andesite, and hornblende-andesite lavas; (3) basaltic and andesitic 


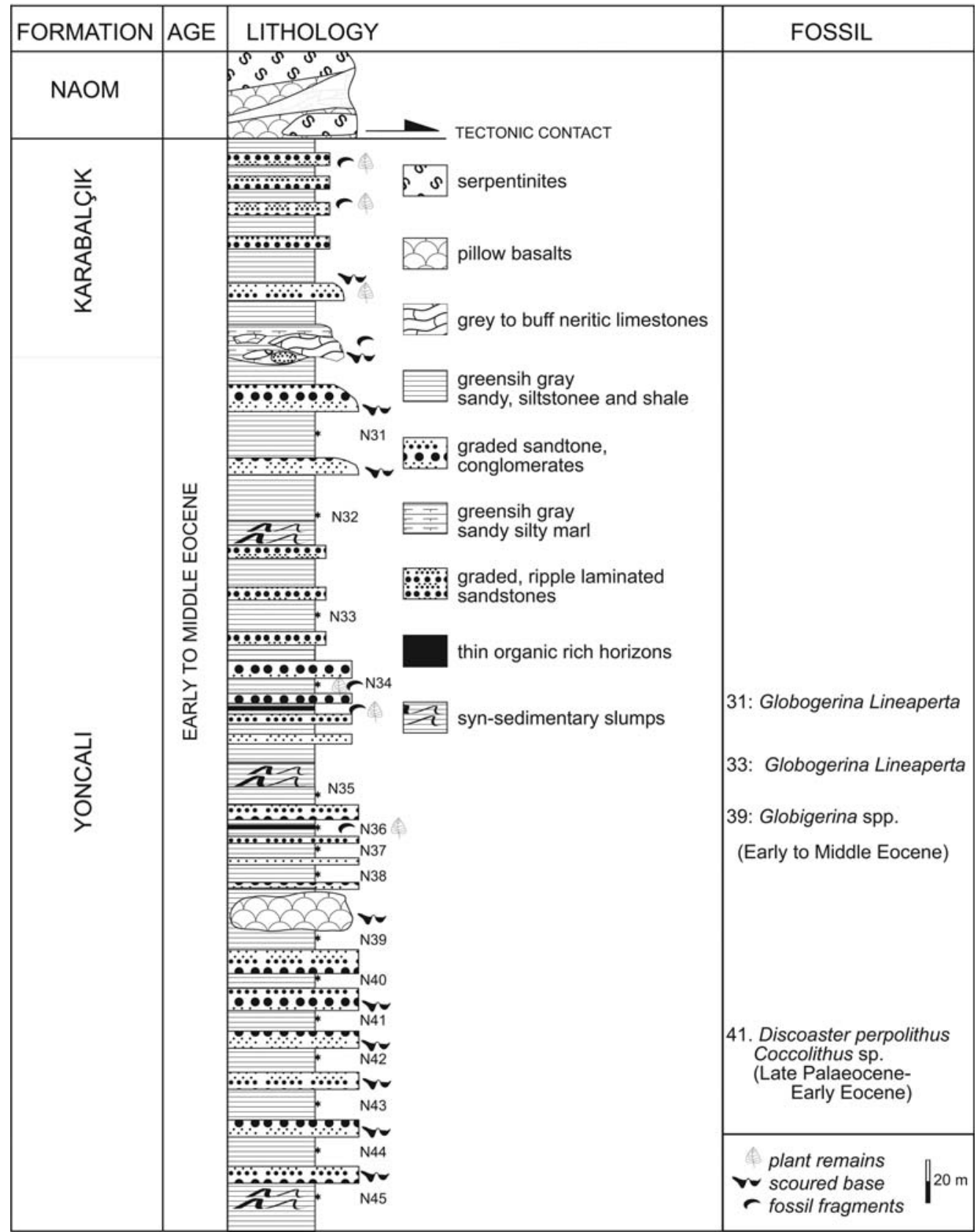

Fig. 12. Measured stratigraphic section for parts of the Yoncalı and Karabalçık formations (its location is indicated with 12 in Fig. 2).

lavas derived from continental crustal setting; and (4) tuffs and agglomerates. In the NE, just outside the studied portion of the Çankırı Basin, a number of generally $\mathrm{W}-\mathrm{NW}$ to E-SE oriented dykes, which may range up to $10 \mathrm{~km}$ in length, have intruded the
NAOM, Yoncalı and Karabalçik formations (Fig. 11c). Based on the similarity of their geochemical characteristics and emplacement ages, these dykes were interpreted to be the feeders of the volcanic rocks of the Bayat Formation. 


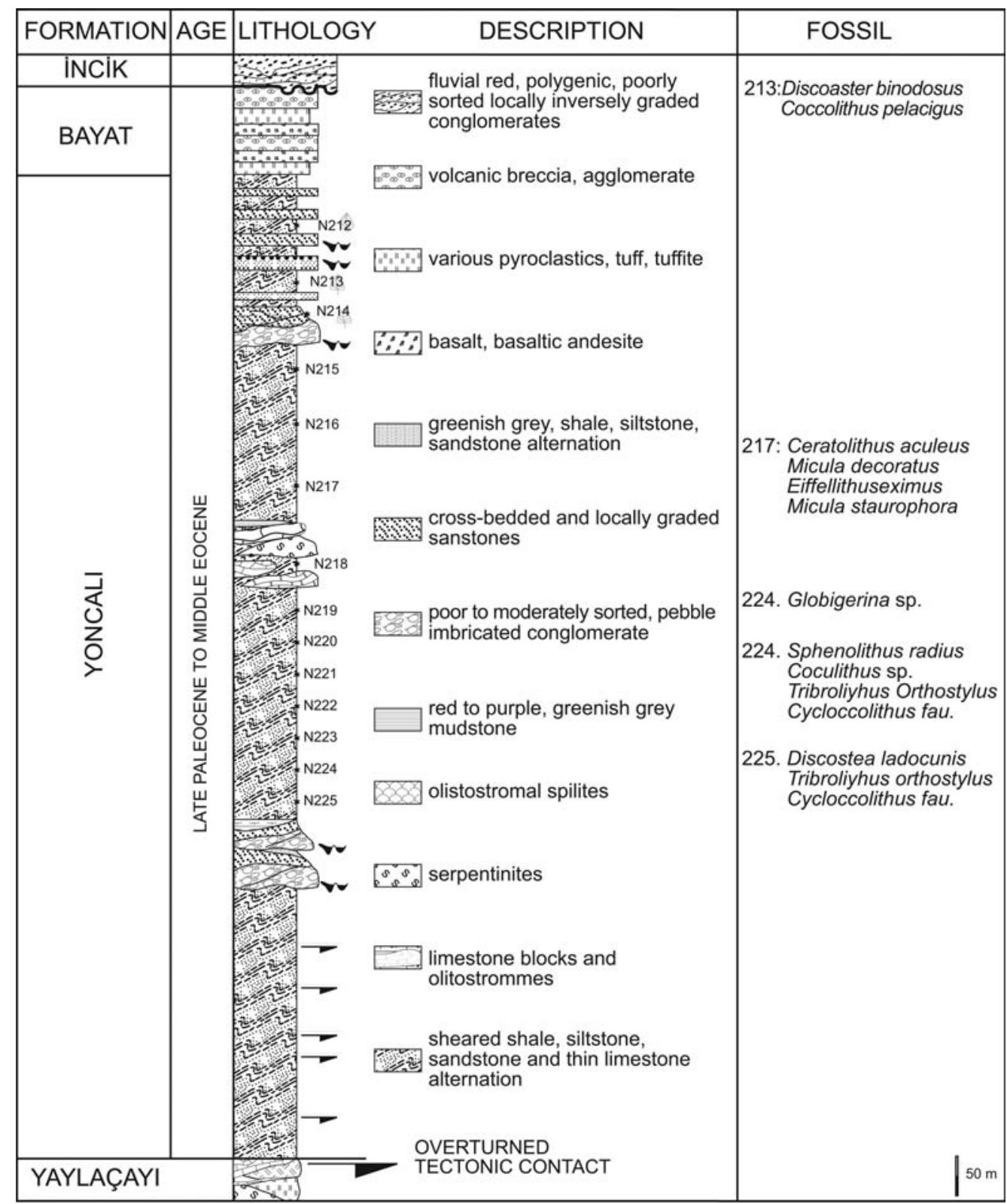

Fig. 13. Measured stratigraphic section for parts of the Yoncalı and the Bayat formations (its location is indicated with 13 in Fig. 2).

In the northeastern part of the Çankırı Basin, the Bayat Formation starts with medium bedded, poligenic conglomerates at the bottom and continues upward with an alternation of green, greenish grey tuffaceous sandstone and marl intercalated with tuff and agglomerates. The age of the Bayat Formation is early to middle Eocene as indicated by its fossil content (Figs $14 \& 17$ ).
Osmankahya Formation (To, lower to middle Eocene). The Osmankahya Formation was first named by Birgili et al. (1974). It is characterized mainly by continental red clastics. Together with the Kocaçay Formation, it locally covers both the basin in-fill and the basement (Fig. 14).

Lithologically, the Osmankahya Formation is composed of conglomerate, sandstone and mudstone 


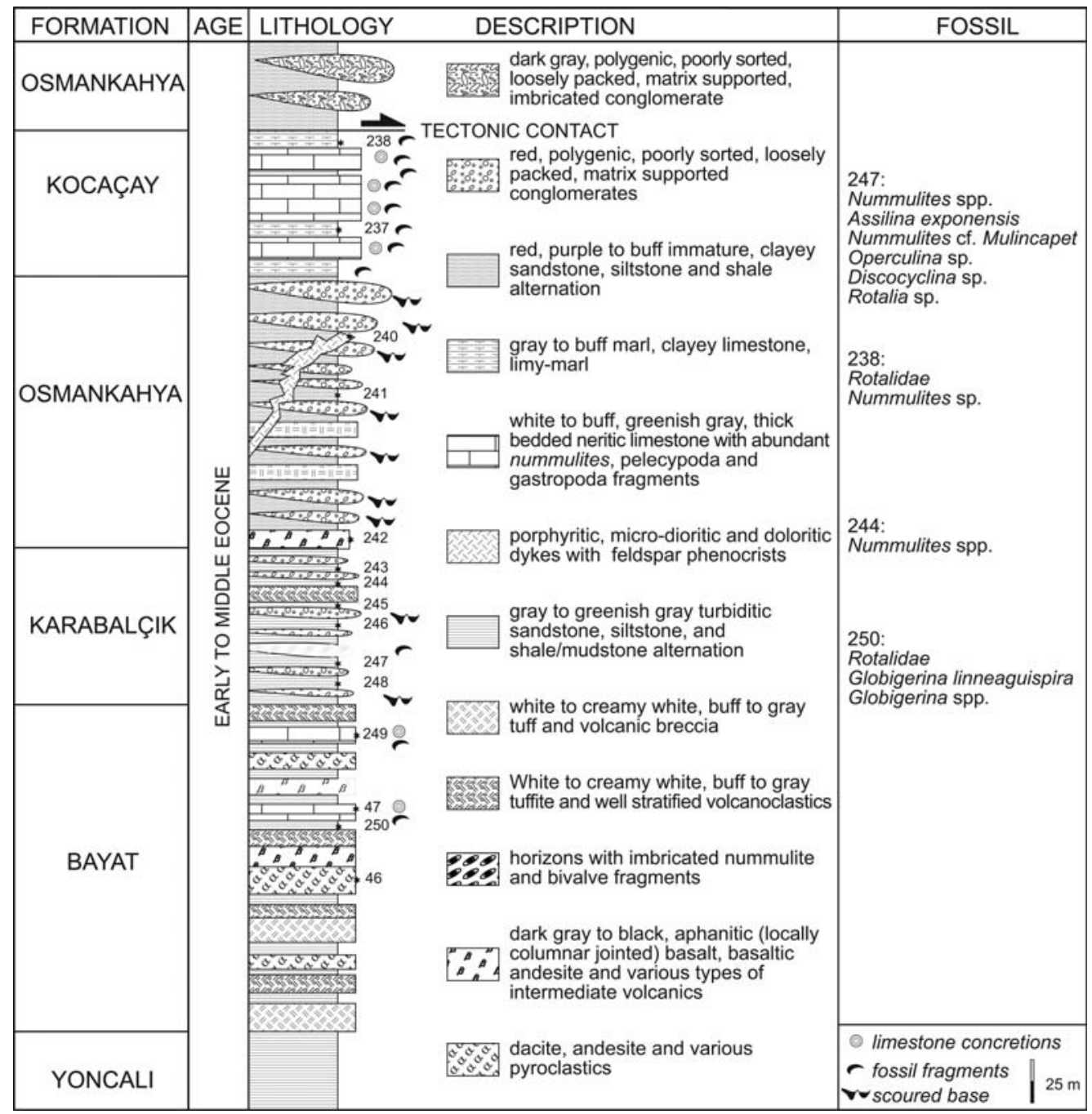

Fig. 14. Measured stratigraphical section for parts of the Bayat, Yoncalı, Karabalçık, and Kocaçay formations. Note that the Bayat Formation underlies the Yoncalı Formation that is generally higher in the stratigraphical position then the Yoncalı and Karabalçı formations (its location is indicated with 14 in Fig. 2).

alternations. In the northern part of the basin, it is characterized by very thick polygenic conglomerates, cross-bedded sandstones and red mudstones intercalated with thin tuffaceous beds. The pebbles of the conglomerates are locally imbricated and sandstones are characterized in some levels by ripple laminations (climbing and symmetrical ripples in places), trough and planar cross bedding and locally by epsilon cross-bedding indicating river channels. The cross-bedded conglomerates may reach up to $20 \mathrm{~m}$ in thickness. In the northern part of the basin, west of İskilip (Fig. 2), cross-beds, pebble imbrications and very large-scale cross- bedding indicate an approximate NW to SE transport direction. In the northeastern part of the basin, the Osmankahya Formation includes interfingering of sandstones containing possibly intraformationally reworked and imbricated nummulite fossils.

In the southwestern part of the study area, the Osmankahya Formation laterally grades into the Karagüney and Mahmatlar formations and is characterized by an approximately $100 \mathrm{~m}$ thick alternation of red and greenish grey sandy mudstones, sandstones and lens-shaped conglomerate bodies. At the top, the unit is characterized by an 


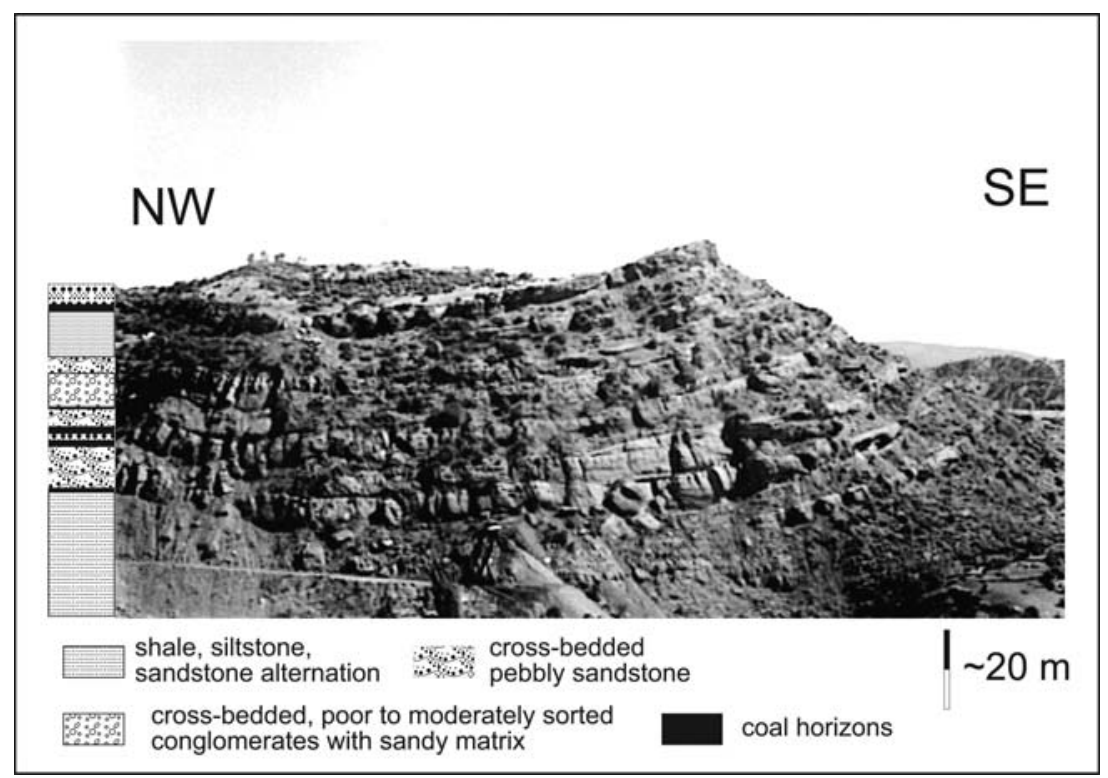

Fig. 15. Photograph of the upper coal bearing parts of the Karabalçik Formation in the northern part of the Çankırı Basin (location is around $\mathrm{N}: 40^{\circ} 43^{\prime} 21^{\prime \prime}, \mathrm{E}: 34^{\circ} 08^{\prime} 50.5^{\prime \prime}$, view to NE).

approximately $10 \mathrm{~m}$ thick purple to brick-red mudstone that grades into the Kocaçay Formation.

In the central parts of the basin, the Osmankahya Formation always forms an interlayer between underlying Kırşehir Block units and overlying Kocaçay Formation. Osmankahya and Kocaçay formation laterally grade into the Karagüney and Mahmatlar formations where Osmankahya Formation is characterized by red to brick-red mudstones and sandstones (Fig. 18).

The age of the unit, based on its stratigraphical position and pollen analysis, is early to middle Eocene (Ünalan 1982; Yoldaş 1982; Dellaloğlu et al. 1992).

Kocaçay Formation (Tko, lower to middle Eocene). This unit was first named by Birgili et al. (1974). It is characterized by a few metres to $100 \mathrm{~m}$ thick nummulitic and macrofossil dominated fossiliferous limestone and locally conglomeratic limestone with intraformationally reworked nummulites. It is one of the key horizons of the basin as it covers both the basin sequences and the basement. It is a condensed sequence and is the youngest marine deposit in the Çankırı Basin.

The Kocaçay Formation is divided into three distinct lithological levels (Figs 17 \& 18). In the northern part of the basin it is composed of brown to dark green, medium bedded, medium to fine-grained tuffaceous sandstone and shale alternation and marl intercalation at the bottom. At the top it is composed of thick-bedded nummulitic limestone (Fig. 17) with thin bedded marl intercalations (Fig. 18). In southeastern part of the study area, it grades into an evaporitic horizon belonging to the Incik Formation. In the southwestern part of the basin, the Kocaçay Formation is exposed in a narrow north-south oriented belt, where it is characterized by nummulites, gastropods and pelecypoda, laterally grading into conglomeratic, nodular limestone levels.

The age of the unit is middle Eocene as indicated by its fossil content (Figs $14 \& 16-18$ ).

\section{Kalınpelit Group}

The Kalınpelit group comprises the post-middle Eocene to Oligocene Incik, Güvendik and Kılçak formations.

Incik Formation (Ti, middle Eocene to Oligocene). The Incik Formation was first named by Aziz (1975). It is characterized by continental red clastics and it is the most widespread and voluminous units in the basin with thickness of more than $2000 \mathrm{~m}$. In general it conformably overlies the Kocaçay Formation except for local internal unconformable relationships observed in the northern and southwestern part of the basin. Local, internal angular unconformities are also observed within the unit and they are interpreted as syntectonic (progressive) unconformities indicative of syntectonic deposition and synsedimentary deformation of the unit. 


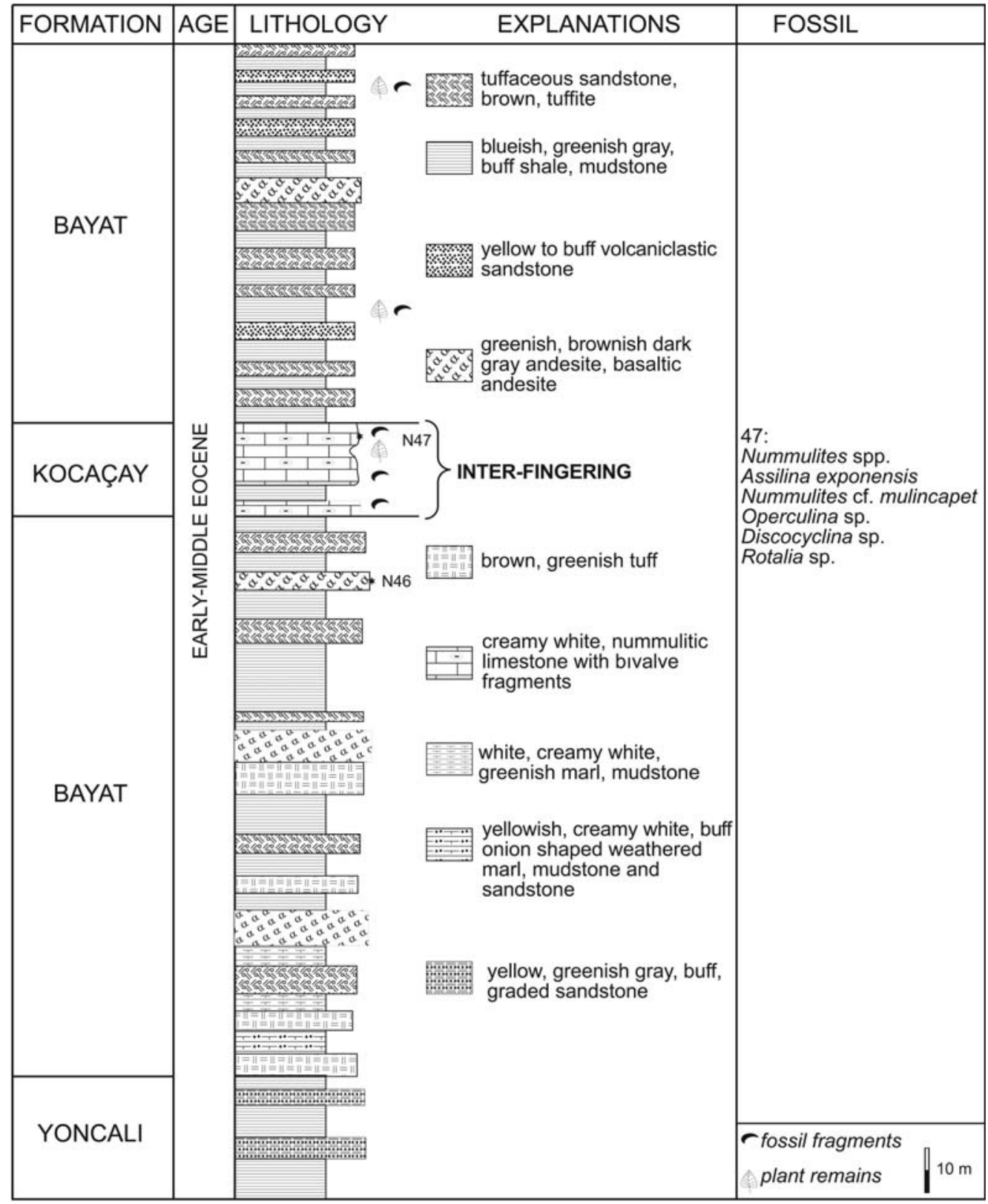

Fig. 16. Measured stratigraphical section for parts of the Bayat and Kocaçay Formations. Note the inter-tonguing of the Kocaçay Formation (its location is indicated with 16 in Fig. 2).

In the northern areas of the basin, the Incik Formation is monotonous with the alternation of very thick-bedded $(c .2 \mathrm{~m})$ red conglomerates alternating with very thick-bedded, poorly sorted, immature red sandstones and purple to brick-red, thickto very thick-bedded mudstones (Fig. 18). The conglomerates and sandstones display lens-shaped patterns which, from north to south, laterally become thinner and finer and finally pinch-out. From north to south, a number of internal angular unconformities coinciding with a number of coarsening upwards sequences are observed in the 


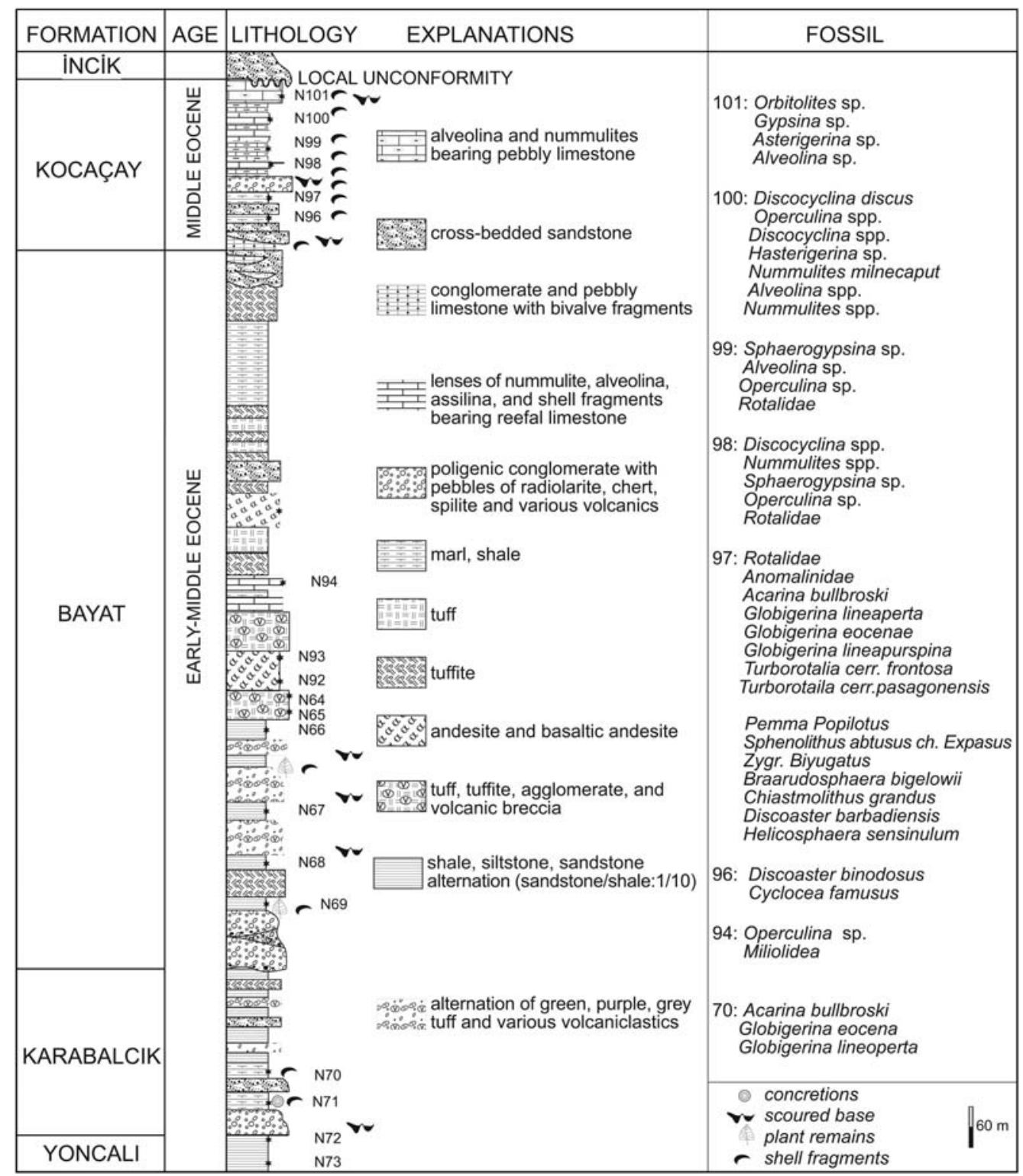

Fig. 17. Measured stratigraphic section for parts of the Karabalçık, Bayat and the Kocaçay Formations (its location is indicated with 17 in Fig. 2).

northern part of the basin. The angular discrepancy between the underlying and overlying sequences of the Incik Formation decreases from north to south. The pebbles are derived mainly from the NAOM and Yaylaçayı Formation, including serpentinites, ultramafics, radiolarites and various volcanic rocks.

In the SW of the basin, the Incik Formation has similar characteristics to its northern counterparts. The grain size, the dips of the bedding, bed thickness and the overall thickness of the unit decrease from west to east and the formation onlap onto the Kırşehir Block (Fig. 19).

It the east, at the bottom it is characterized by yellow to brick-red thinly bedded gypsum, which laterally and vertically grades into green shale and is the oldest gypsum observed in the field. The color of the shale gradually changes from green to red and finally into purple. It is approximately 


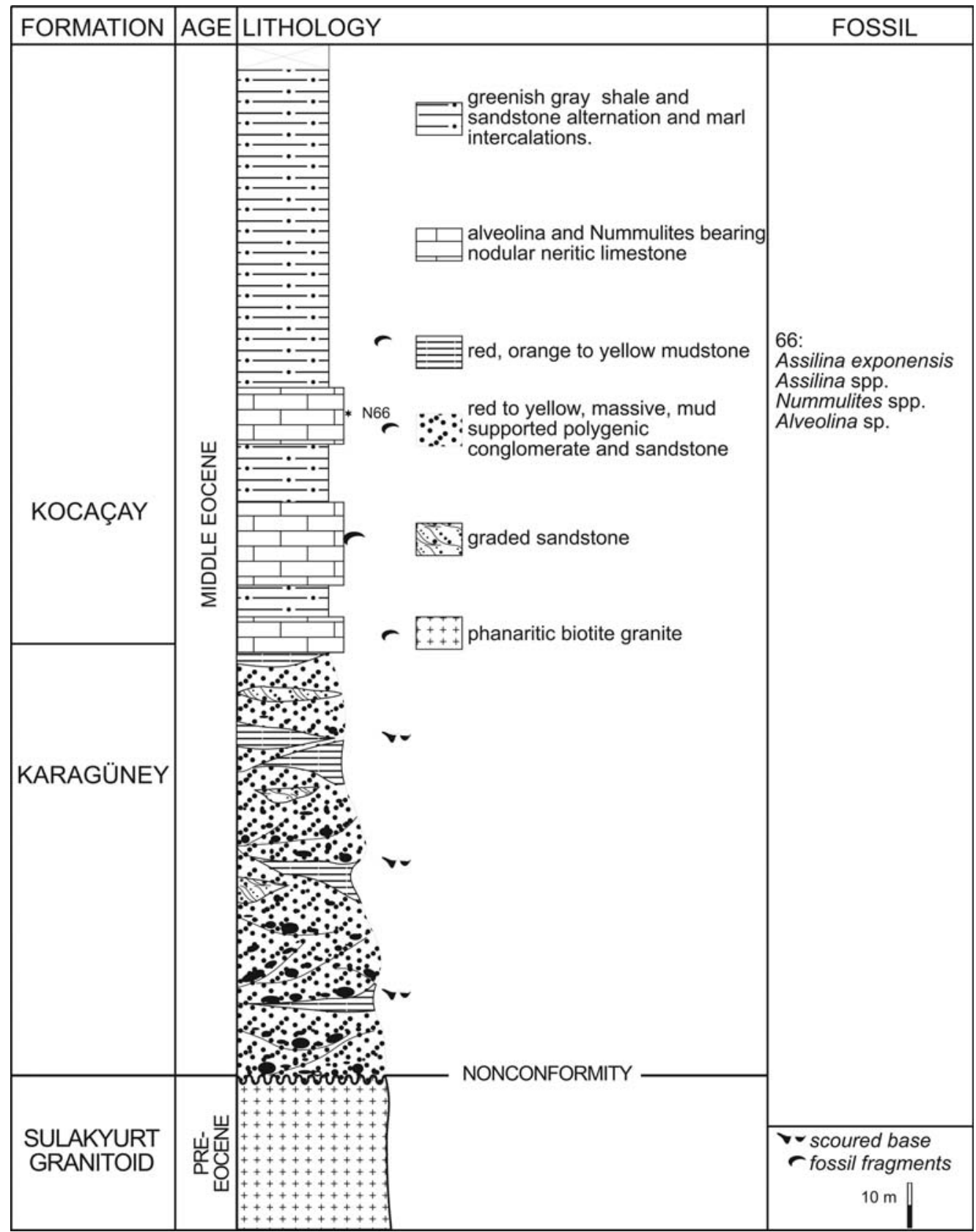

Fig. 18. Measured stratigraphic section for parts of the Osmankahya and the Kocaçay Formations. (its location is indicated with 18 in Fig. 2).

$50 \mathrm{~m}$ thick. The sequence is followed upwards by thin to medium bedded $(10-50 \mathrm{~cm})$, brick-red to purple, ripple laminated, tabular cross-bedded sandstones alternating with red to purple, siltstone and silty-mudstones. Higher up in the section, the sequence is characterized by an alternation of brick-red to purple sandstones, siltstones, shale and greenish grey to bluish grey shale and very thick-bedded $(1-2 \mathrm{~m})$ red to orange gypsum horizons. The sequence gradually becomes coarser 


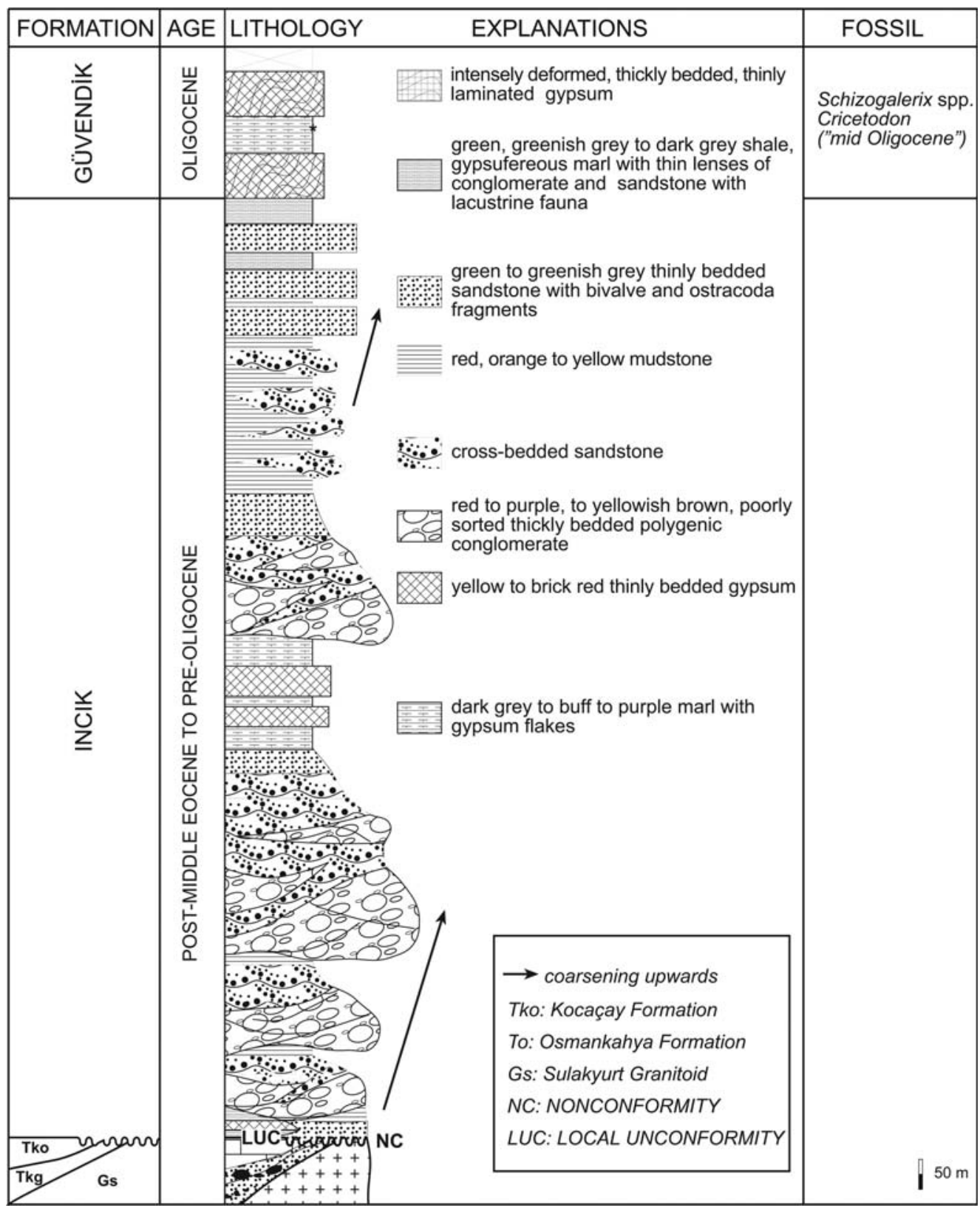

Fig. 19. Generalized stratigraphic section for parts of the İncik and Güvendik formations (İncik formation is partly modified after Dellaloğlu et al. 1992).

grained and thicker bedded. In the upper parts, the unit is characterized by approximately $500 \mathrm{~m}$ of monotonously alternating thick- to very thick-bedded polygenic conglomerates, and red sandy to silty shales. The overall sequence coarsens upwards and only in the top most $100 \mathrm{~m}$ of the unit displays a fining upward sequence. As in the other parts of the basin, internal angular unconformities are frequently encountered in the eastern part of the basin.

In the Sağpazar-1 well (Fig. 2), the Incik and Kocaçay formations interfinger and the Incik Formation is characterized by a very thick sequence of $>2000 \mathrm{~m}$ of evaporites, conglomerates, sandstones and shale alternations. The evaporites include gypsum, 
anhydrite and rock-salt which are being mined around the town of Çankırı and $20 \mathrm{~km} \mathrm{SW}$ of Sungurlu.

The age of the Incik Formation is not known precisely, because of a lack of fossils. Based on its relation with the underlying lower to middle Eocene Kocaçay Formation and the Oligocene Güvendik Formation, the age of the formation is middle Eocene to Oligocene.

Güvendik Formation (Tg, Oligocene). The Güvendik Formation was named for the first time by Kaymakc1 et al. (2001a). Although, the Güvendik formation is intensely deformed, three distinct levels can still be recognized (Fig. 19). At the bottom and the top, it is composed of very thickbedded, finely laminated and intensely deformed gypsum alternating with thin to medium bedded buff to creamy white gypsifereous marls. In the middle, it is composed of greenish grey shales frequently scoured by lenses of micro-conglomerates. In the eastern part of the Çankırı Basin (Fig. 2) the shales include very thin organic horizons with fresh water gastropoda and pelecypoda fragments. In the samples collected from the Güvendik and Gözükızıllı sites (19 in Fig. 2) Eucricetodon sp. (only incisors), Ctenodactylidae; and Tataronyinen n.gen. n.sp. rodent fossils were encountered. Based on these rodents, an Oligocene age is assigned to the Güvendik Formation (Fig. 19).

Kılçak Formation. The Kılçak Formation is the youngest unit related to foreland basin evolution of the Çankırı Basin. It is exposed only in the western margin of the Çankırı Basin. It unconformably overlies all of the older units of the Çankırı Basin and it is tectonically overlain by the NAOM along one of the western boundary-thrust faults of the basin. It is composed of fluvio-lacustrine conglomerate, sandstone, shale and organic rich horizons. According to De Bruijn \& Saraç (1992); De Bruijn et al. (1992); De Bruijn \& Koenigswald (1994); and Ünay (1994) it is of Aquitanian age based on micro-mammals (see Kaymakc1 et al. $2001 a$, for full account of the unit).

\section{South derived units}

Sivritepe group. Outcrops of the south derived units in the southwestern part of the basin contain detritus that was shed mainly from the Kirşehir Block (i.e. Sulakyurt granitoid and the ophiolitic units intruded by the Sulakyurt granitoid) and are interfingering with the North Derived units around NW of Kirıkkale. Their importance is because they record the age of exhumation of Sulakyurt granitoid. The Sivritepe Group comprises the upper Paleocene to middle Eocene Karagüney and Mahmatlar formations.
Karagüney (Tkg) and Mahmatlar Formations (Tma) (upper Paleocene to middle Eocene). The Karagüney and Mahmatlar formations (Fig. 20) are exposed only in the southwestern part of the Çankırı Basin. The stratigraphic position of these two formations is very different from any other unit of the basin sequence of the Çankırı Basin because they are the oldest units which are resting directly on the Kirşehir Block (Figs 2 \& 21), and include detritus derived mainly from the Sulakyurt granitoid and the intruded ophiolites. The Karagüney and Mahmatlar formations were first named and described by Norman (1972).

The Karagüney formation (Fig. 20) is composed of reddish conglomerates characterized by subangular blocks and boulders derived from ophiolites in a fining upwards sequence. The granitic clasts are observed only in the upper parts of the unit and they reach up to $50 \mathrm{~cm}$ in diameter. The boundary relations of the Karagüney Formation with other units are indicated in Figure 4. The thickness of the unit is about $100 \mathrm{~m}$.

The Mahmatlar Formation (Fig. 20) is characterized mainly by detritus derived from the granitoids. It includes sub angular to ellipsoidal granite and ophiolite related boulders and blocks at the bottom. The grain size rapidly decreases and the matrix becomes more limey and nummulite fossils become dominant from bottom to top and from north to south. In the upper parts of the formation, arkosic sandstones dominate. The thickness of the unit is variable and reaches a maximum of about $200 \mathrm{~m}$.

The sub-angular blocks and boulders indicate that they were not transported over long distances and were more likely derived from the underlying nearby ophiolitic units that are associated with the Kırşehir Block, rather than the ophiolites at the rim of the basin. The presence of mainly ophiolite pebbles in the Karagüney Formation and granitic pebbles in the overlying Mahmatlar Formation indicate an inverse stratigraphical relationship during the erosion and transportation processes; such that, first the ophiolitic cover was eroded away, followed by the underlying granitoids (i.e. progressive unroofing) (Fig. 21b).

In the study area, no fossils have been recovered from the Karagüney and Mahmatlar formations within the studied portion of the Çankırı Basin, although very wide spread Nummulites sp. and Assilina sp. fossils were encountered south of Kirikkale (Fig. 2). In addition, these two units laterally grade into the upper Paleocene to middle Eocene İskilip Group (Fig. 21a) which allows correlation between the two areas. Based on this relationship, the Karagüney and Mahmatlar formations are interpreted to have been deposited in the late Paleocene to middle Eocene. 


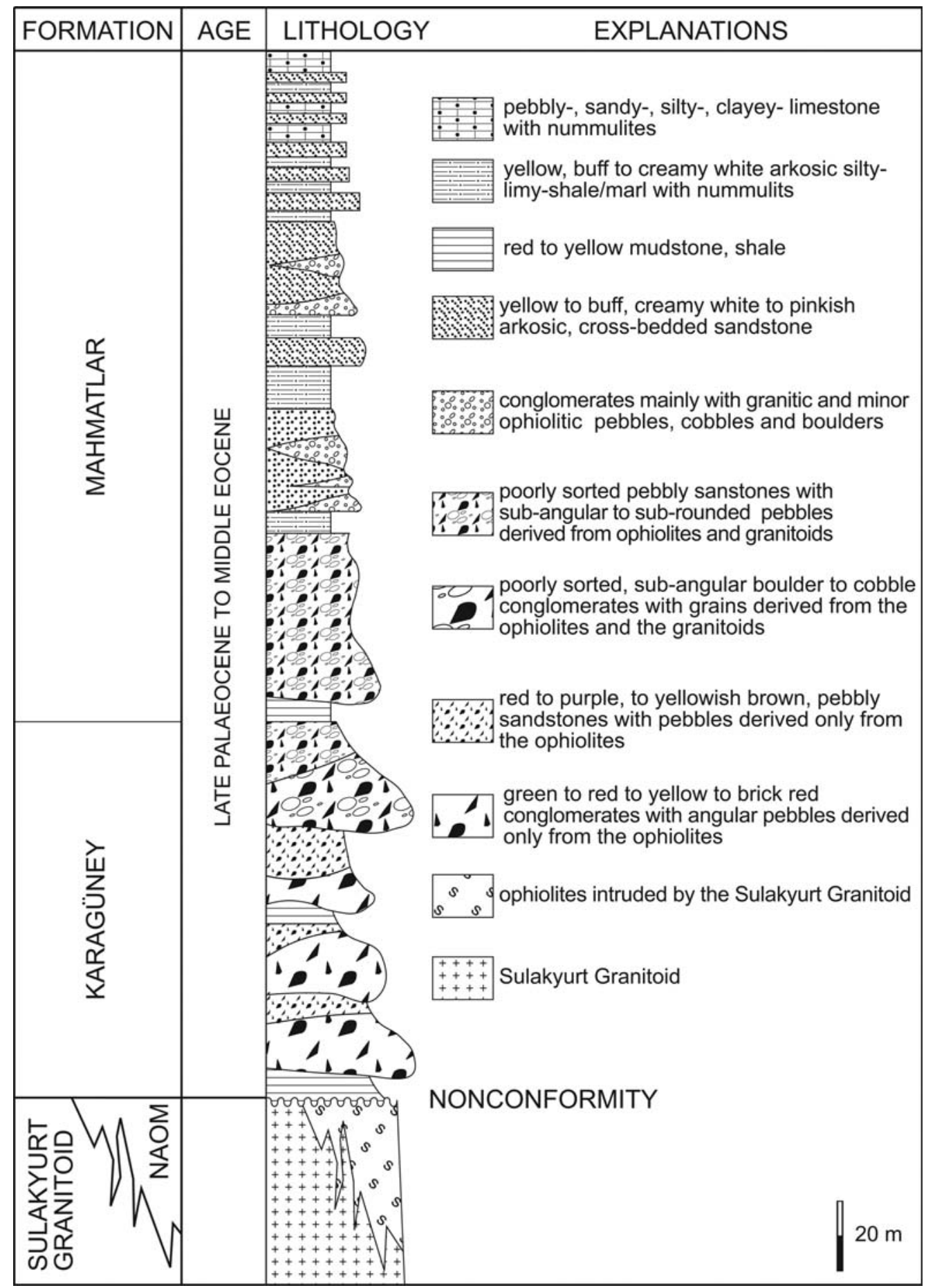

Fig. 20. Generalized stratigraphical section for parts of the Karagüney and Mahmatlar Formations (modified after Norman 1972). 


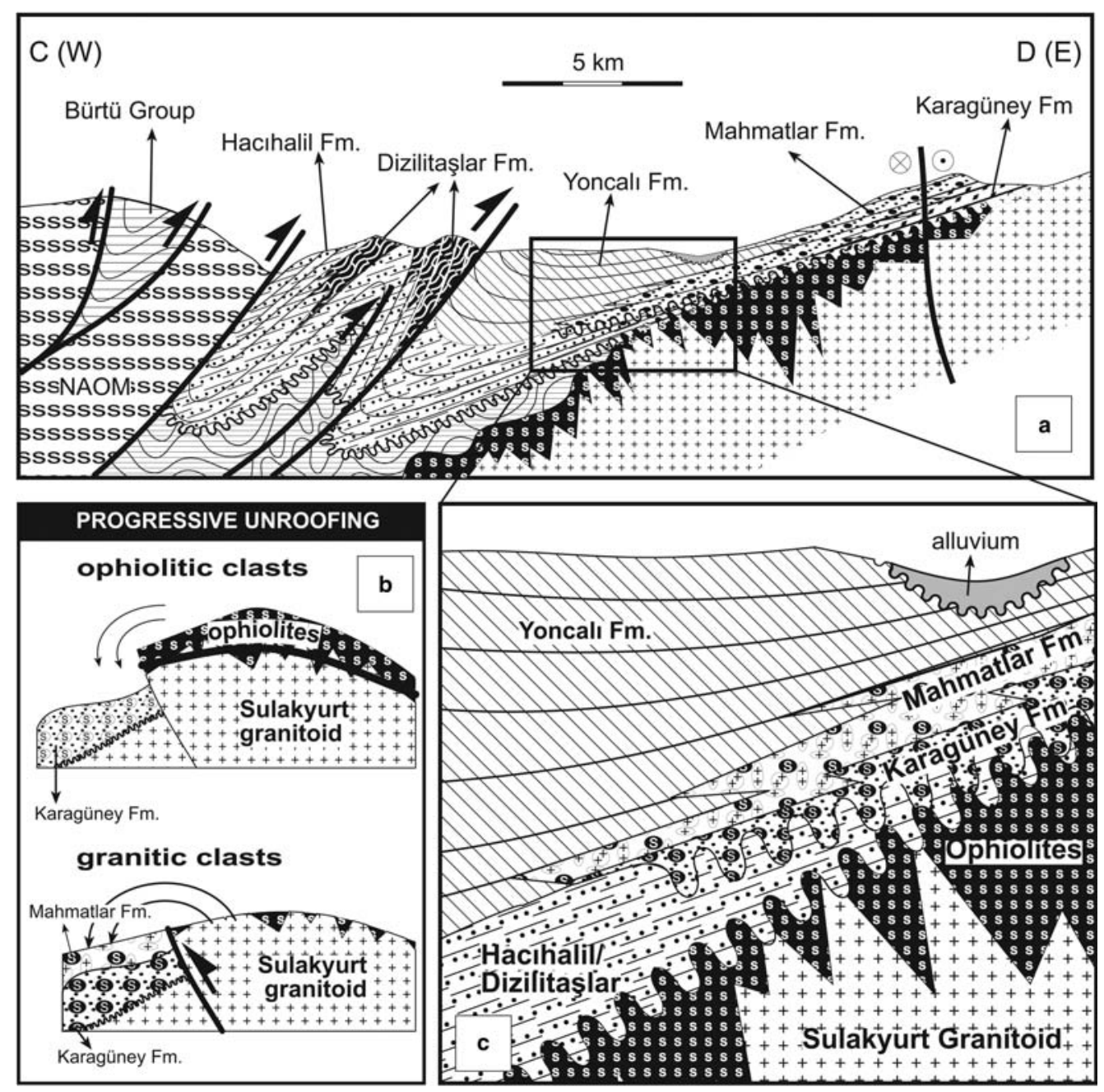

Fig. 21. (a) Sketch cross-section along the line C-D (in Fig. 2). (b) Conceptual cross-sections illustrating the progressive un-roofing of the granites of the Kırşehir Block and its reflection in the Karagüney and Mahmatlar Formations. (c) Blow-up figure depicting the relation between some of the north derived units (Hacihalil, Dizlitaşlar and Yoncalı formations) and the south derived units (Karagüney and Mahmatlar formations).

\section{Discussion}

\section{Temporal relationships}

A correlation chart for pre-middle Miocene of the Çankırı Basin is presented in Figure 22. Due to repeated tectonic activity, which is characterized by two distinct thrusting events in the late Cretaceous to early Miocene and later by extensional (middle Miocene) and, finally, by regional transcurrent tectonics (late Miocene to recent) (see Kaymakc1 et al. 2000, 2001b, 2003a), the boundary relationships and lateral continuity between individual formations are partly obliterated. The most noticeable boundary relationships observed, in relation to the evolution of the Çankırı Basin, are the syntectonic unconformities between different formations and frequently within the same formation (e.g. Incik Formation). The types of unconformities encountered in the field are depicted in Figure 23 and are reflecting tectonic activity during deposition.

The oldest syntectonic unconformities are observed between the Yaylaçay1 (Ky) and the Malıboğazı formations $(\mathrm{Km}$; indicated by 1 in Fig. 22) and between the Yapraklı and Kavak formations (indicated by 2 in Fig. 22) in the northwestern part of the Çankırı Basin. This unconformable 


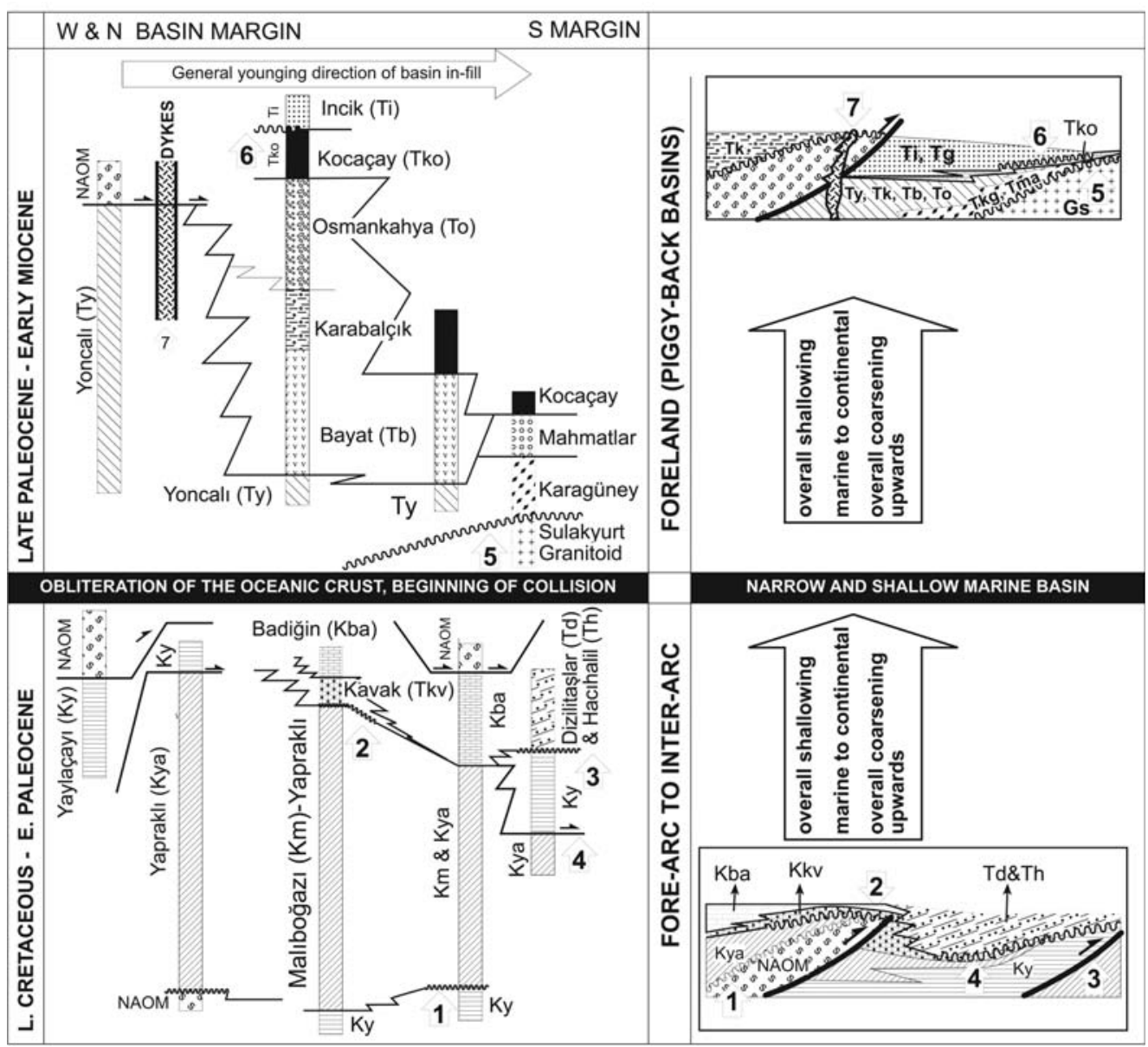

Fig. 22. Correlation chart for pre-middle Miocene formations of the Çakırı Basin (see text for discussion).

boundary in turn is angular unconformably overlain by the Incik Formation (Fig. 23a). The Kavak Formation unconformably overlies the thrust contact between Yapraklı and Yaylaçayı formations (indicated by 3 in Fig. 22) and Yaylaçayı and Yapraklı formations are unconformably overlain by the Hacihalil and Dizlitaşlar Formations (indicated by 4 in Fig. 22). These relationships are interpreted as the indication of syn-depositional thrusting during the deposition of the Yapraklı and Kavak formations in which general tectonic transport direction occurred from NW to SE (in present day orientations) (Figs $2 \& 22$ ).

The same relations are also observed in the upper Paleocene to lower Miocene units. The oldest unconformity is observed between the Sulakyurt granitoid and the upper Paleocene-middle Eocene units in the southwestern part of the basin (5 in Fig. 22). A very well developed syntectonic unconformity is also observed within the Incik Formation itself and between Incik and the formations of the
İskilip Group (6 in Figs 22 \& 23b \& c). These relationships are indicative of differential uplift due to tectonic activity and contemporaneous sedimentation during the late Paleocene to middle early Miocene. Having syntectonic unconformities within the İskilip and Kalınpelit Groups near the rim of the Çankırı Basin and onlap of these units onto the basement indicate progressive migration of the depocenter southwards onto the Kurşehir Block from the late Paleocene onwards.

The most evident boundary relationship with respect to timing of thrusting is observed in the northeastern corner outside of the study area (11c in Fig. 22). There, a number of North-NWto SouthSWoriented feeder dykes for the volcanic rocks of the Bayat Formation cut the thrust contact between the underlying Yoncalı Formation and the overlying NAOM (Fig. 11c). This indicates that thrusting occurred before and/or during the deposition of the Bayat Formation in the early to middle Eocene. 

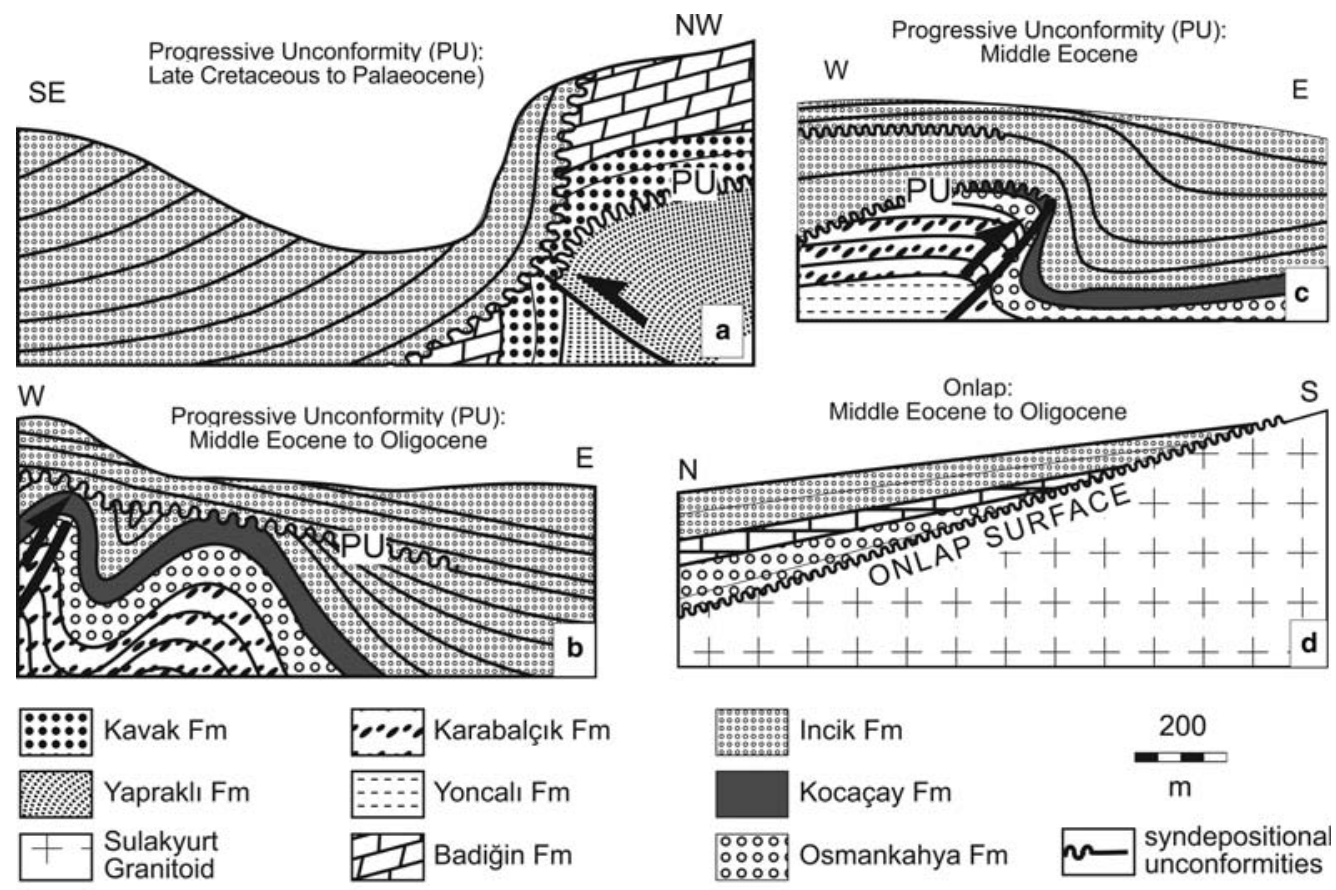
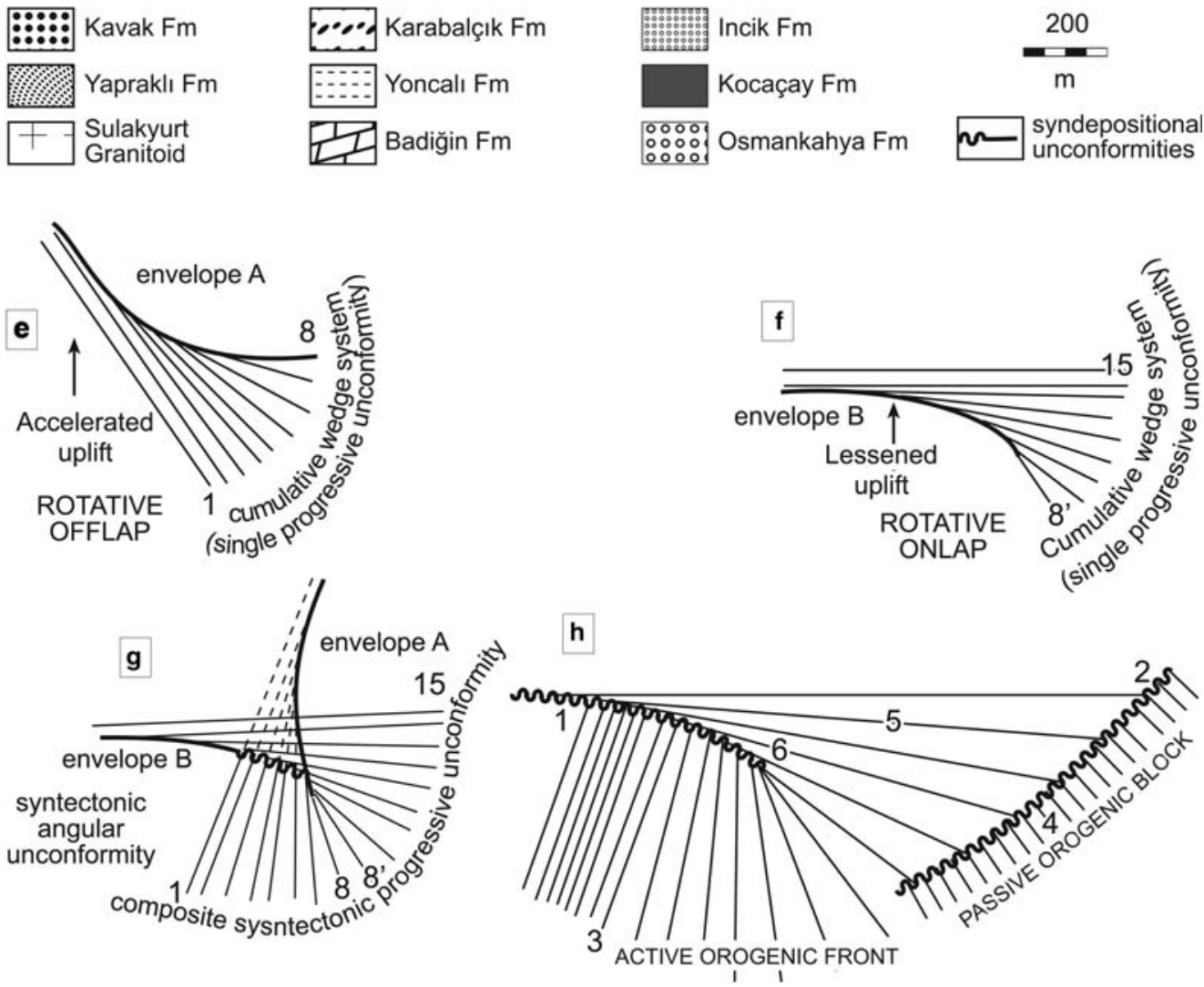

Fig. 23. (a-d) Sketch cross-sections illustrating the various types of syntectonic unconformities observed during the field studies. $(\mathbf{e}-\mathbf{h})$ Conceptual development of syntectonic unconformities in areas where deformation and deposition are coupled. The numbers 1-15 are the time lines (adopted from Riba 1976). 
Although, it is tectonically disturbed by thrust faults, the contacts between the upper Cretaceous and upper Paleocene to Eocene units is locally unconformable, not only in the Çankırı Basin but also further SW outside of it (Norman 1972; Görür et al. 1984). This relationship is very important regarding the tectonic evolution of the basin. It infers that the tectonism and accompanying sedimentation was continuous from the late Cretaceous to Eocene. However, the southwestern reworked upper Cretaceous to Paleocene fauna in the Yoncalı and Karabalçık formations in the southwestern part of the basin implies that the boundary between the upper Cretaceous to Paleocene formations and the upper Paleocene to middle Eocene formations must at least be a local unconformity as depicted in Figures 21-23. This relationship implies two possibilities. The first one was that there is no major change in the style of tectonics but the local unconformable relationship between the upper Cretaceous and upper Paleocene to Eocene units is a syntectonic unconformity and, consequently, thrusting and sedimentation were coeval but the unconformably relationship is enhanced due to local uplifts related to ongoing thrusting. The second possibility is that the local unconformable relationship between the upper Cretaceous to lower Cenozoic units indicates a major and complete change in the style of tectonic activity. The second option seems to be the more likely considering: (1) the major change in the palaeostress configurations (radial compression) (Kaymakc1 et al. 2000, 2003a); (2) Palaeomagnetic constraints (oroclinal bending during the early Cenozoic, Kaymakc1 et al. 2003b); (3) and the regional tectonic scheme as evidenced by widespread un-roofing of granitoids and exhumation of metamorphic rocks in the Kurşehir Block (Erler \& Bayhan 1995; Whitney et al. 2001; Boztuğ \& Jonckheere 2007; Boztuğ et al. 2007); (4) the youngest age obtained from the ophiolitic mélange as being late Maastrichtian which implies an end of ophiolitic mélange formation; and (5) termination of arc volcanism in the Maastrichtian (Tüyüz et al. 1995; Sunal \& Tüysüz 2002; Rice et al. 2006). Based on these relationships, it is concluded that lower Paleocene marks the end of subduction, obliteration and complete subduction of the Neotethyan oceanic crust and collision of the Kirşehir Block and the Sakarya Continent. Therefore, collision of the Kurşehir Block and the Sakarya Continent took place at the end of late Cretaceous.

\section{Depositional environments and lateral gradations}

The Yaylaçayı Formation is locally incorporated into the NAOM, which indicates that deposition of the Yaylaçayı Formation and generation of mélange (NAOM) were contemporaneous. The Yaylaçayı Formation was deposited within forearc to interarc environments and includes volcanic rocks and volcanoclastic rocks derived from the arc and seamount setting (Tüysüz et al. 1995; Rojay et al. 2001, 2004; Rice et al. 2006). The Yapraklı Formation is time equivalent of the Yaylaçayı Formation deposited in shallower and proximal depositional settings (for alternative explanation, see Rice et al. 2006). Lateral gradation of the Malıboğazı Formation with the Yapraklı Formation and the presence of rudist fossils indicate that the Malıboğazı Formation was deposited in areas where the water depth was shallow enough for rudists and other benthic fauna to survive and which indicates gradual shallowing of depositional environments due to differential uplift. The rudist bearing units, in the Ankara region, were deposited at the crest of an accretionary wedge (Rojay \& Süzen 1997), which was locally and intraformationally deposited uplifted and eroded to supply detritus, together with the NAOM, to the other proximal units including the Kavak and Badiğin formations.

The Kavak and Badiğin formations laterally grade and overlie the Yapraklı Formation with a local unconformity. They were deposited in a transitional continental to marine (mixed) environment in which the proximal facies are categorized as Kavak and distal facies are categorized as Badiğin formation (Fig. 22). The presence of sub-angular blocks and boulders derived from the NAOM and from the other upper Cretaceous units indicate that the Kavak formation was deposited close to its source whence the NAOM, Yaylaçayı and Yapraklı formations must have been exposed and eroded locally. A local unconformable relationship between the Kavak and Yapraklı formations indicates ongoing sedimentation and tectonic activity that resulted in contemporaneous local uplift due to thrusting. A similar relationship is also observed between the Yapraklı and Hacihalil formations (Figs 5 \& 22). These observations indicate that thrusting occurred along with thrust-related sedimentation during the Paleocene. The presence of plant remains and dominance of terrigeneous material in the Yapraklı Formation and in the other Paleocene units, the dominance of continental settings in many areas of Turkey (Gökten 1983; Görür et al. 1984, 1998; Okay et al. 1996; Gürer \& Aldanmaz 2002) indicates that the depositional environments were bordered by land masses and marine areas were restricted.

The İskilip Group comprises mainly marine formations and has lateral gradations with each other. Among these, the lower part of the Hacihalil Formation is deposited in a continental setting and gradually becomes marine as it grades into the Yoncal1 Formation. The Yoncal1 Formation 
represents the more basinal facies of the group and is characterized by a turbiditic sequence and deeper marine shales and clays. The Karabalçık Formation is represented by conglomerates with local coarsening upwards sequences. The Osmankahya Formation overlies the Karabalçık Formation and was deposited mainly in continental settings interfingering with marine settings. The Kocaçay Formation covers all of these units and is characterized by a condensed sequence of nummulitic limestones. The Bayat Formation is represented mainly by volcanic and volcanogenic units embedded within the İskilip Group (upper Paleocene to middle Eocene). The Incik Formation is characterized mainly by continental deposits that laterally grades and overlies all the other formations of the İskilip Group. It also includes local unconformities developed progressively during the activity along the thrust faults and is associated with coarsening upwards sequences. The Güvendik formation was deposited within lacustrine settings as evidenced by the presence of lacustrine fauna. The Kılçak Formatin is deposited in fluvio-lacustrine settings.

The organization of facies and structures indicate presence of thrust regime in the early Cenozoic. These include mezoscopic syn-sedimentary thrust faults (Kaymakc1 et al. 2000, 2003a), wedge-like infill patterns which contain progressive syntectonic unconformities, facies and major thrust faults become younger from the basin rim towards the centre, and southwards migrated depocenters.

Based on the information discussed above, in association with seismic data (see Kaymakc1 2000), the depositional environments of the lower Cenozoic in-fill of the Çankırı Basin has been reconstructed (Fig. 24). It has already been discussed that the palaeocurrent directions in the Hacihalil sector of the Çankırı Basin indicates mainly southeastward, with minor northward, sediment transport directions, which indicate that the basin rim was exposed locally in the northeastern part of the Çankırı Basin (11c in Fig. 2) during the deposition of the Hacihalil Formation. The local unconformities, southward transport of the thrusts, which was accompanied by deposition both in the front and the rear of the thrust faults, indicates that the Çankırı Basin evolved within a thrust regime with associated piggy-back basins (terminology after Ori \& Friend 1984), in the late Paleocene to early Miocene (Fig. 24).

\section{Evolutionary scenarios of the Çankırı Basin}

As discussed previously tectonically there are two distinct episodes in the evolution of the region. The first one took place in the Late Cretaceous to Paleocene interval and related to the subduction of the Neotethys oceanic crust, whilst the second one belongs to collision and post-collisional convergence period in the late Paleocene to early Miocene.

\section{Late Cretaceous to middle Paleocene}

Northward subduction of the Neotethys oceanic crust below the Pontides commenced earlier than Cenomanian (Saner 1980; Şengör \& Yılmaz 1981; Okay 1984; Dellaloğlu et al. 1992; Okay et al. 1994, 1996, 2001; Tüysüz et al. 1995; Kaymakc1 2000; Robertson 2002; Clark \& Robertson 2005; Rice et al. 2006), possibly in the early Cretaceous regarding the opening of the Western Black Sea as a backarc basin (Görür 1988, 1997; Okay et al. 1994, 2006; Robinson et al. 1997; Tüysüz 1999; Tüysüz \& Tekin 2007). The subduction occurred along two trenches (Fig 25a-c). The southern one is an intra-oceanic subduction zone associated with an ensimatic arc (Fig 25a \& b). During the Turonian, obduction of the N-Morb ophiolitic crust commenced during which supra-subduction zone ophiolites begin to form (Yalınız et al. 2000) while the ensimatic arc split and rifted away (Fig. 25c). Supra-subduction zone ophiolite generation is thought to be the consequence of decrease in convergence rates of Taurides (including the Kırşehir Block) and the Pontides (including the Sakarya Continent) and possibly slab roll-back. These processes may also account for the backarc extension and opening of the western Black Sea Basin. During the end of the Santonian (83.5 Ma), a new northwards subduction started (Fig. 25d) in the north along which the supra-subduction zone ophiolitic crust was consumed and later obducted on to the Kırşehir Block (Fig. 25 d \& e) (Yalınız et al. 1996). This new subduction event might have given way to formation of an ensialic arc development (Yemişliçay Formation of Tüysüz et al. 1995, and Tüysüz 1999) and formation of a forearc basin south of it (Rice et al. 2006), in which the Yaylaçayı and Yapraklı formations were deposited. The Yapraklı Formation represents the proximal facies of the forearc basin as implied by neritic carbonates and terrigeneous clastics, while the Yaylaçayı Formation represents more basinal facies (Figs 25a-c).

In the Campanian, the supra-subduction zone ophiolites obducted onto the Kirşehir Block and gave rise to the thickening and main metamorphism in the Kırşehir Block crust during which oldest granitoids in the Kirşehir Block intruded (Akìman et al. 1995; İlbeyli et al. 2004; Boztuğ et al. 2007), while in the north, around the Çankırı Basin and its western (towards the Tuzgölü Basin) and eastern extensions (towards the Sivas Basin) the basin narrowed and deep sea conditions were progressively replaced by shallower conditions along the 


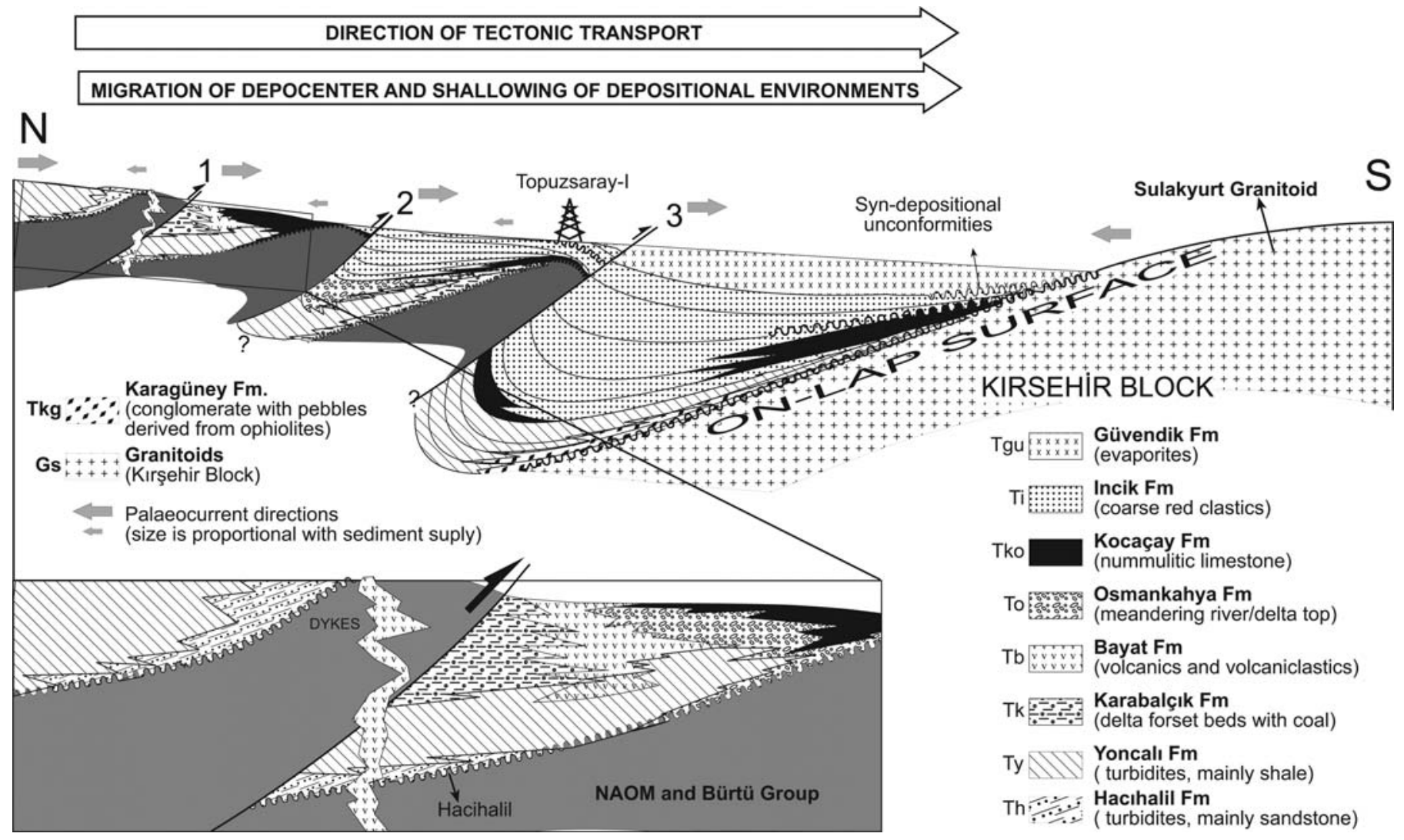

Fig. 24. A conceptual cross-section illustrating early to middle Eocene to early Miocene coupling between thrusting and coeval deposition. Numbers 1-3 are the sequences of thrusts, which developed during the kate Paleocene to early Miocene. Note that the dykes of the Bayat Formation cross-cut the thrust contact between the NAOM and the Yoncalı Formation. 


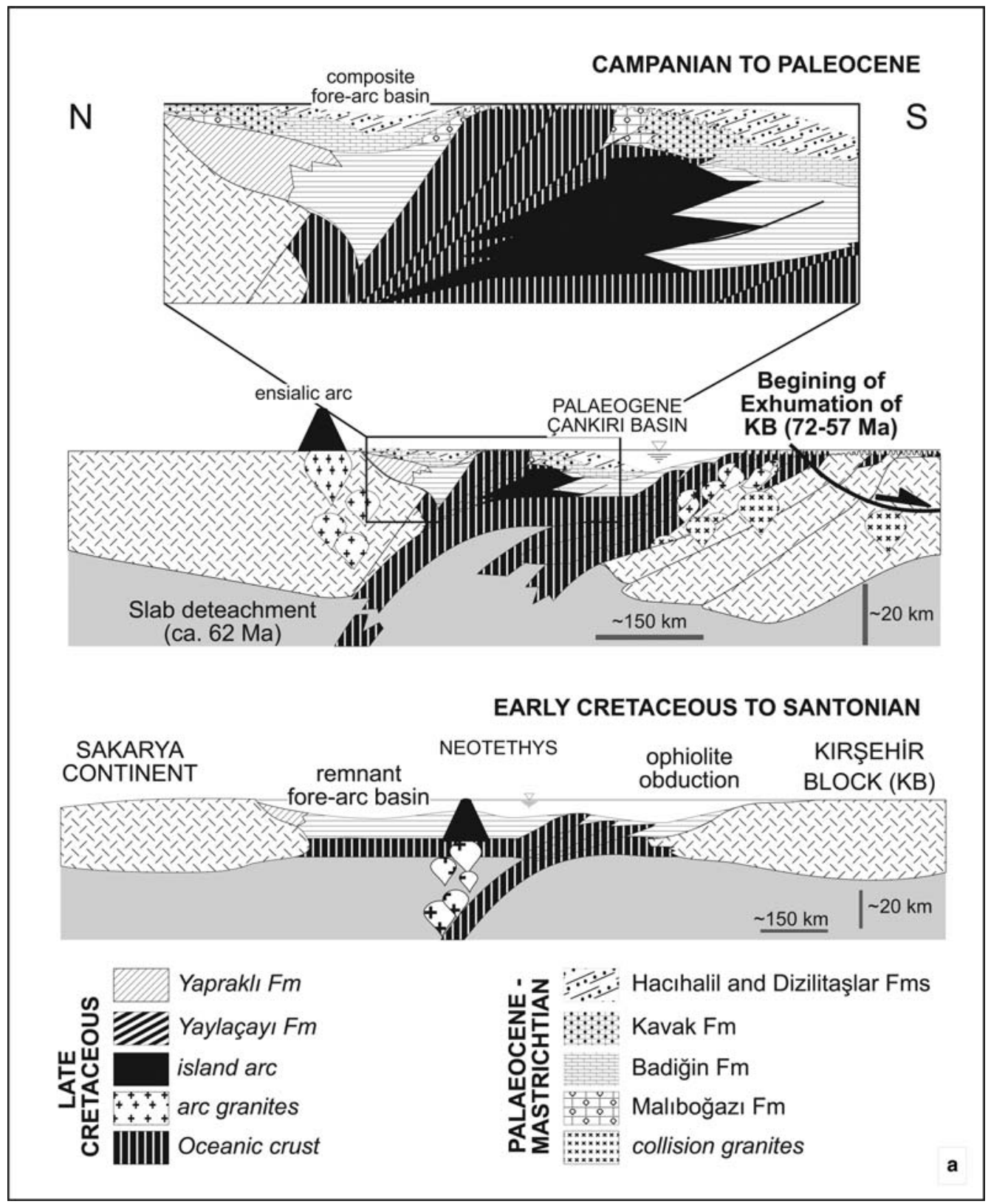

Fig. 25. Conceptual evolutionary scenarios. (a) cross-sections for the early Cretaceous to Paleocene.

margins of the basin (Fig. $25 \mathrm{~d} \&$ e). Due to thrust stacking in the margins of the Çankırı Basin, ophiolitic units (rim) were uplifted and sub-aerially exposed, and supplied detritus to the Yapraklı Formation, and later to the Kavak and Badiğin formations. In the shallower settings of the rim the
Malıboğazı Formation is deposited as isolated patch reefs (Fig. 25e).

Obliteration of the intervening oceanic crust gave way to termination of subduction and collision of the Kırşehir Block and the Sakarya Continent at the end of the Maastrichtian (Fig. 25e). This in 


\section{EARLY CRETACEOUS-TURONIAN}

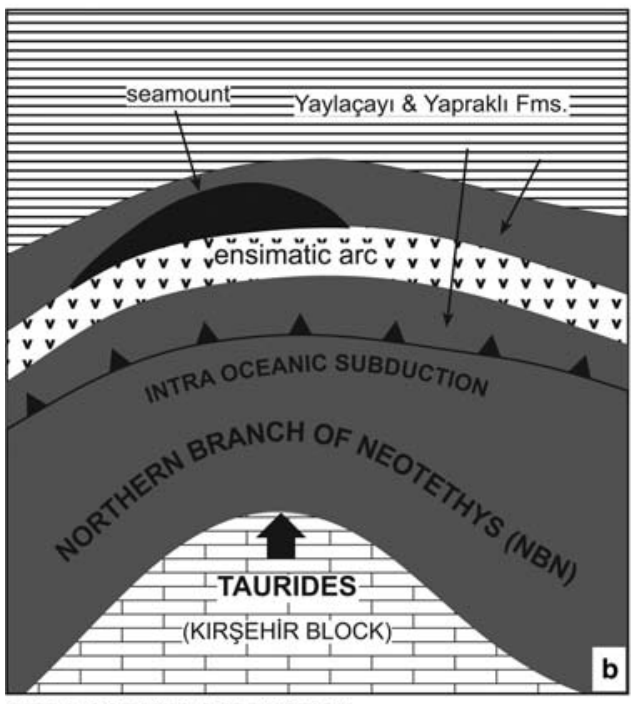

INTRA-OCEANIC SUBDUCTION

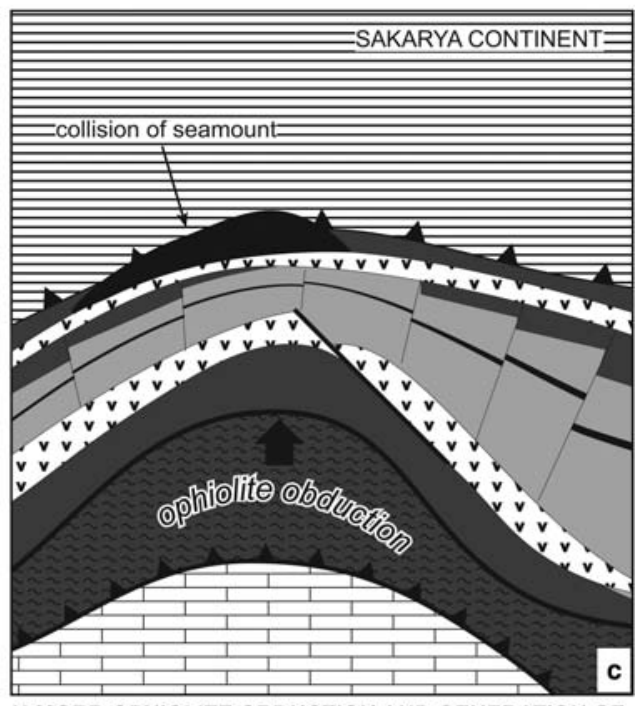

N-MORB OPHIOLITE OBDUCTION AND GENERATION OF SUPRA-SUBDUCTION (SSZ) OPHIOLITES AND SPLITING OF THE ENSIMATIC ARC (Turonian).

BEGINNING OF ANDEAN TYPE SUBDUCTION (Santonian)

\section{MAASTRICHTIAN - LATE MIDDLE PALEOCENE}

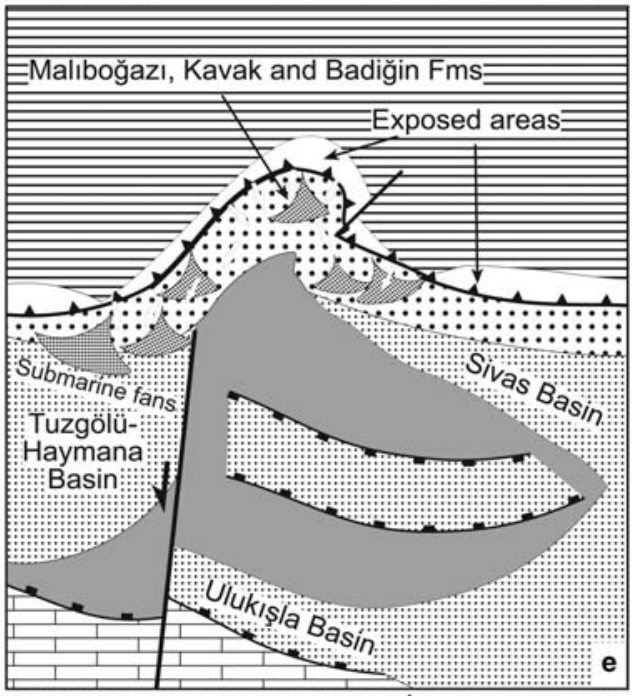

COLLISION BETWEEN THE KIRSEHIR BLOCK AND THE PONTIDES. BEGINNING OF EXHUMATION OF THE GRANITOIDS AND THE METAMORPHIC ROCKS OF THE KIRŞEHIR BLOCK ( 72-57 Ma)

Fig. 25. (b-e) palaeogeographial scenarios for the early Cretaceous to Maastrichtian interval.

turn, gave way to disruption of the forearc basin which was extending almost all along the subduction front (i.e. İzmir-Ankara-Erzincan Suture Zone). During the end of the late Cretaceous to
Paleocene, deposition partly continued only in the deeper parts of the Çankırı Basin. Therefore, the early Cenozoic configuration of the Çankırı Basin is superimposed on a part of the upper Cretaceous 


\section{LATE PALAEOCENE TO EARLY MIOCENE}

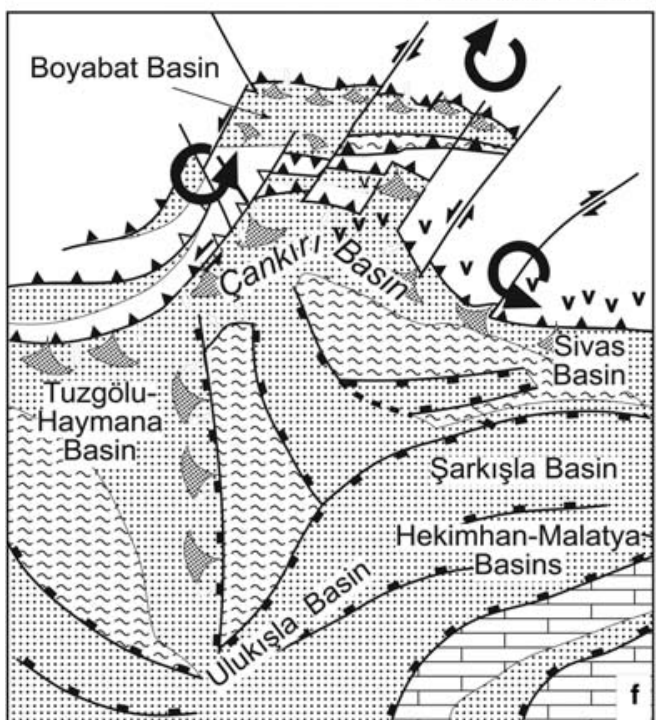

PIGGY-BACK BASINS (NORTH),

EXHUMATION AND UNROOFING OF

GRANITES CONTINUED (SOUTH) (72-57 Ma)

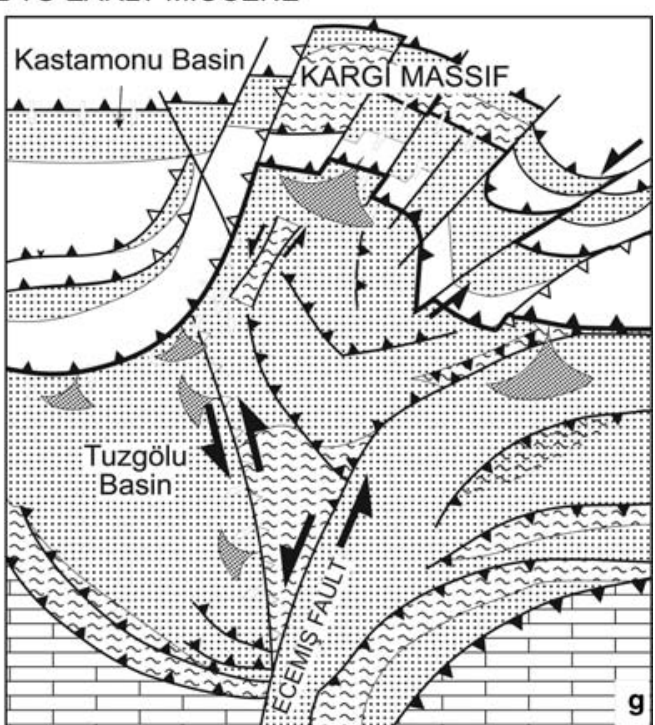

MAJOR COMPRESSIVE PHASE, INVERSION OF EXTENSION RELATED BASIN (Late Eocene - Oligocene)

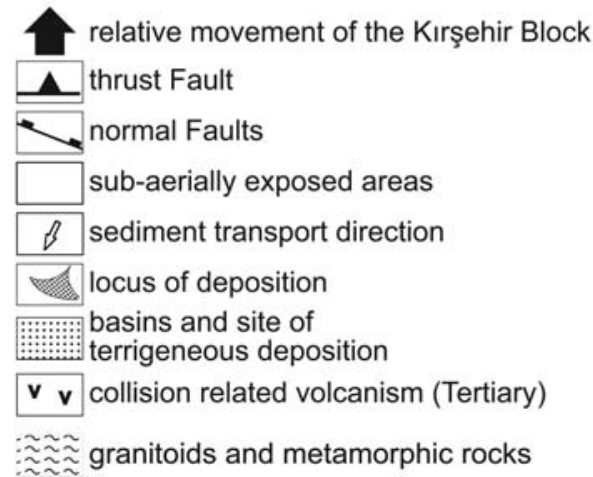

Fig. 25. (f-g) palaeogeographial scenarios for the Paleocene to early Miocene interval.

fore-arc basin (Figs 25 \& 26) without a major depositional break.

By the end of the Maastrichtian, the oceanic domains were completely consumed, ophiolitic mélange generation and volcanism ceased due to collision of the Kırşehir Block with the Sakarya Continent (continent-continent collision) (Fig. 25f). We speculate that this gave way to detachment of the slab which in turn resulted in a rapid uplift and decrease in the convergence rates between the Pontides and the Kırşehir Block. This might have resulted in extension and exhumation of metamorphic rocks and the granitoids of the Kırşehir Block (Boztuğ et al. 2007; Boztuğ \& Jonckheere 2007). Extension in the Kirşehir Block continued until the middle Paleocene during which the Çankırı Basin was uplifted and still under slight compression as evidenced indirectly by erosion of the upper Cretaceous units, onset of continental to shallow marine conditions and relatively limited amount of deposition (Kavak and Badiğin formations). From the late Paleocene onwards, metamorphic rocks and granitoids of the Kırşehir Block were subjected to erosion (Erler \& Bayhan 1995; Çemen et al. 1999; Gautier et al. 2002; Boztuğ \& Jonckheere 2007).

\section{Late Paleocene to early Miocene evolution of the Çankırı Basin}

The late Paleocene to early Miocene evolution of the Çankırı Basin is characterized by foreland 


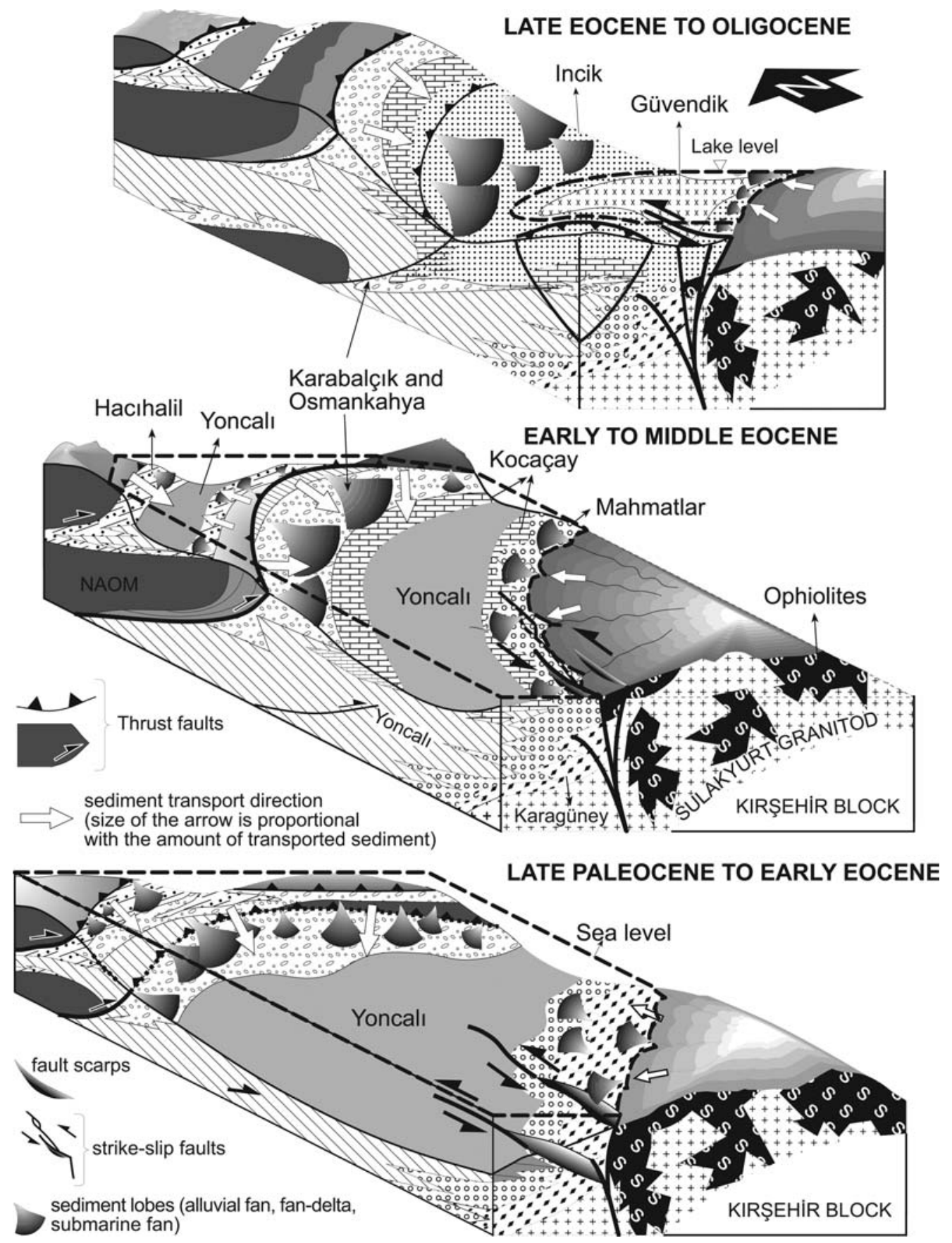

Fig. 26. Block diagrams illustrating the late Paleocene to early Miocene evolution of the Çankırı Basin (see text for discussion). 
basin deposition due to collision and further convergence of the Sakarya Continent and the Kırşehir Block (Figs 25f, g \& 26). The reconstruction of the depositional environments for the upper Paleocene to lower Miocene sequences of the Çankırı Basin is illustrated in Figure 26. The upper Paleocene to Eocene is characterized by very rapid lateral and vertical facies changes, a consistent relative younging of units from the rim towards the basin centre which onlap progressively onto the flexurally subsiding Kirşehir Block. Deposition of the Hacıhalil and Dizlitaşlar Formations continued during the late Paleocene and they display facies associations ranging from proximal alluvial fan, to braided river, to meandering river, to fan delta, to near shore and to prodelta/open marine facies (Ocakoğlu \& Çiner 1997). The Hacihalil Formation is laterally transitional and always underlies the Yoncalı Formation. This relationship may indicate a gradual relative rise of the sea level (Weijers et al. 2007) that caused fining upwards sequences and a relative deepening of depositional environments from continental to a deeper marine facies. Alternation of graded sandstone, siltstone, shale and the presence of current ripples indicate that the Yoncalı Formation was deposited by turbidity currents. Considering its position relative to the Karabalçık and Osmankahya formations, it may represent prodelta clays, near shore clastic settings to deep marine settings (cf. Reading \& Collinson 1996). The presence of benthic fauna, plant remains and coal seams indicate that the Karabalç1k Formation was deposited in relatively shallow marine conditions, which laterally and/or temporally changed into marshy conditions. The large-scale cross-bedding and the presence of boulders and blocks within the conglomerates, as well as the presence of channels of conglomerates of the Karabalçık Formation within the Yoncalı Formation indicates that the Karabalçık Formation constitutes the foreset beds of a south facing delta. The channels in the Yoncalı Formation may indicate a distributary channel system of this delta (cf. Postma \& Roep 1985; Johnson \& Baldwin 1996; Reading \& Collinson 1996). The Osmankahya Formation was deposited in a prograding near shore setting where fluvial deposition was the dominating agent. The Kocaçay Formation laterally grades over, and covers all the Eocene units. The presence of benthic foraminifera (e.g. nummulites, alveolinae etc.) and bivalves and locally presence of conglomerates and sandstones indicates that the Kocaçay Formation was deposited in a very shallow water conditions. The Incik Formation is deposited in continental settings. Its lateral gradation to the Kocaçay Formation and the presence of greenish grey shale with marine fauna indicate a continental to marine transition (mixed environment). The presence of evaporates indicates arid climate conditions.

The youngest depositional unit related to postcollisional convergence and hence foreland basin development is continued until the Aquitanian and is represented by the Kilçak Formation.

\section{Conclusions}

The tectonostratigraphical evolution of the Çankırı Basin occurred mainly in two main episodes. The first one took place in the late Cretaceous to Paleocene and the second in the late Paleocene to earliest Miocene.

The late Cretaceous to Paleocene evolution of the basin was associated with the northwards subduction of the northern Neotethys under the Sakarya Continent. Two different subduction events took place in the region. The oldest event is an intra-oceanic subduction that resulted in an ensimatic arc and supra-subduction zone ophiolite generation that in turn obducted onto the Kırşehir Block. The second subduction event took place during the Santonian-Maastrichtian interval and produced an ensialic arc on the Sakarya Continent. The earliest sub-aerial emergence of the rim occurred in the Maastrichtian. It is thought that the emergence of the rim was associated with the accretionary wedge growth enhanced by collision of the sea mount with the Sakarya Continent. In the south of the sea mount, the Çankırı Basin continued to its evolution as a remnant basin which was relatively narrowed due to subduction. During the Maastrichtian, in the periphery of the emergent areas, the Malıboğazı, Kavak and Badiğin formations were deposited while in the relatively deeper parts, deposition of Yaylaçayı and Yapraklı formations continued. Rapid uplift and emergence occurred during the Paleocene which gave way to increased sediment supply and development of turbiditiy currents.

By the beginning of the Paleocene, the overthickened Kirşehir Block due to obduction and nappe stacking, began to collapse which subsequently gave way to un-roofing of the granitoids and exhumation of the metamorphic rocks of the Kırşehir Block. Un-roofing and exhumation is evidenced by presence of granitic and metamorphic pebbles in the Paleocene deposits in the Çankırı Basin and elsewhere.

By the late Paleocene, indentation of the Kırşehir Block into the Sakarya Continent began (Kaymakc1 et al. 2003b). This gave way to development of a foreland basin system characterized by a series of piggy-back basins. Due to southwards migration of the thrust faults and the depocenters, the 
depositional environments became shallower and finally passed into continental settings by the end of the middle Eocene. During the post- middle Eocene to early Miocene, the basin became completely restricted and the sea withdrew perpetually from the region. Since the end of the middle Eocene continental conditions have been prevailing in the region. The collision and indentation related convergence and basin development in the Çankırı Basin lasted until the Aquitanian (early Miocene, c. $20 \mathrm{Ma}$ ). From the Burdigalian onwards a new tectonic regime established in the Çankırı Basin (see Kaymakc1 et al. 2001b).

We thank D. J. J. Hinsbergen, S. Rice and O. Tüysüz for critical reviews. This study is supported by Turkish Government under YLS - grant and Turkish Petroleum Co. The authors would like to thank Y. Öztaş for field support. H. de Bruijn, E. Unay and G. Saraç are acknowledged for micro-mammal sampling and identifications.

\section{References}

Akiman, O., Erler, A., GöncüoĞLU, M. C., GÜleÇ, N., Geven, A., TÜreli, T. K. \& KAdioĞLU, Y. K. 1993. Geochemical characteristics of granitoids along the western margin of the Central Anatolian Crystalline Complex and their tectonic implications. Geological Journal, 28, 371-382.

Akyürek, B., Bilginer, E., Akbaş, B., Hepsen, N., Pehlivan, S., Sunu, O., Soysal, Y., DaĞer, Z., Çatal, E., Sözeri, B., Yildirim, H. \& HAKYEMEZ, H. 1984. The geology of the AnkaraElmadağ-Kalecik region. Chamber of Geological Engineers of Turkey Bulletin. 20, 31-46.

AYAN, T. 1969. Çankırı-Yerköy havzası petrol imkanları: Jeolojik ve Tektonik etüdü. Egeran Müşavirlik Mühendislik Firması. TPAO Rap. No: $\mathbf{4 6 9}$ (unpublished).

AzIZ, A. 1975. Ískilip civart ile güney ve güneybatısının detay jeolojisi ve petrol olanaklart. M.T.A. Arş. Rap. No: 6132 (unpublished).

BINGÖL, A. F. 1984. Geology of the Elazig area in the Eastern Taurus Region. Proceed. of the Geology of the Taurus Belt, MTA, Ankara, 209-216.

Birgili, S., Yoldaş, R. \& ÜNAlAn, G. 1974. ÇankırlÇorum havzast jeolojisi ve petrol olanaklart ön raporu. TPAO Rap. No: 1216 (unpublished).

Boztŭ̆, D. \& Jonckheere, R. C. , 2007. Apatite fission-track data from central-Anatolian granitoids (Turkey: constraints on Neo-Tethyan closure. Tectonics, 26, TC3011, doi:10.1029/2006TC001988.

BoztuĞ, D., Tichomirowa, M. \& BombACH, K. 2007. ${ }^{207} \mathrm{~Pb}-{ }^{206} \mathrm{~Pb}$ single-zircon evaporation ages of some granitoid rocks reveal continent-oceanic island arc collision during the Cretaceous geodynamic evolution of the central Anatolian crust, Turkey. Journal of Asian Earth Sciences, 31, 71-86.

Çemen, İ., GöncưoĞlu, M. C. \& Dirik, K. 1999, Structural Evolution of the Tuzgölü Basin in Central Anatolia, Turkey. Journal of Geology, 107, 693-706.

Clark, M. \& Robertson, A. 2005. Uppermost Cretaceous-Lower Cenozoic Ulukışla Basin, south-central
Turkey: sedimentary evolution of part of a unified basin complex within an evolving Neotethyan suture zone. Sedimentary Geology, 173, 15-51.

DE BRUiJn, H. \& SARAÇ, G., 1992. Early Miocene rodent faunas from eastern Mediterranean area. Part II. Mirabella (Paracricetodontinae, Muroidea). Proceedings of the Koninklijke Nederlandse Akademie Van Wetenschappen, Amsterdam, B95, 25-40.

De Bruijn \& Koenigswald, W. 1994. Early Miocene rodent faunas from eastern Mediterranean area. Part V. The genus Enginia (Muroidea) with a discussion of the structure of the incisor enamel. Proceedings of the Koninklijke Nederlandse Akademie Van Wetenschappen, Amsterdam, B97, 381-405.

De Bruijn, H., DAAms, R., DAXNer-Höck, G., Fahlbusch, V., Ginsburg, L., Mein, P. \& Morales, J. 1992. Report of the RCMNS Working Group on fossil mammals. Reisensburg 1990. Newsletter on Stratigraphy, 26, 65-118, Berlin, Stuttgart.

DellaloĞlu, A. A., Tüysüz, O., Kaya, O. H. \& HARPUT, B. 1992. Kalecik (Ankara)-Eldivan-Yaprakll (Çankırı)-İskilip (Çorum) ve Devrez Çayı arasindaki alanın jeolojisi ve petrol olanakları. TPAO Rap. No. 3194 (unpublished).

DEMIRER, A., ÖZÇÉLIK, Y. \& ÖZKAN, R. 1992. ÇankırlÇorum basenindeki Eosen volkanitlerinin petrografisi. TPAO Rap. No. 1810 (unpublished).

Dickinson, W. R. \& SEELY, D. R. 1979. Structure and stratigraphy of forearc regions. AAPG Bulletin, 63 , $2-31$.

DiriK, K., GöncüoĞLu, M. C. \& Kozlu, H. 1999. Tectonic evolution of the southwestern part of the Sivas Basin. Geological Journal, 34, 303-319.

ERler, A. \& BAYHAN, H. 1995. Orta Anadolu Granitoidleri'nin genel değerlendirilmesi ve sorunları. Hacettepe Üniversitesi Yerbilimleri, 17, 49-67.

Gautier, P., Bozkurt, E., Hallot, E. \& Dirik, K. 2002. Pre-Eocene exhumation of the Niğde Massif, Central Anatolia, Turkey. Geological Magazine, 139, $559-576$.

GÖKTEN, E. 1983. Şarkışla (Sivas) ğuney-güneydoğusunun stratigrafisi ve jeolojik evrimi. Türkiye JeolojiKurumu Bülteni. 26, 167-176.

GöRÜR, N. 1988. Timing of opening of the Black Sea Basin. Tectonophysics, 147, 247-262.

GÖRÜR, N. 1997. Cretaceous syn- to postrift sedimentation on the southern continental margin of the western Black Sea Basin. In: Robinson, A. G. (ed.) Regional and Petroleum Geology of the Black Sea and Surrounding Region. American Association of Petroleum Geologists, Memoir, 68, 227-240.

Görür, N., TÜysüZ, O. \& ŞENGÖR, A. M. C. 1998. Tectonic evolution of the central Anatolian basins. International Geological Review, 40, 831-50.

Görür, N., Oktay, F. Y., Seymen, I. \& ŞEngör, A. M. C. 1984. Palaeotectonic evolution of the Tuzgölü basin complex, Central Turkey: Sedimentary record of a neotethyan closure. In: DIXON, J. E. \& Robertson, A. H. F. (eds) The Geological Evolution of the Eastern Mediterranean. Blackwell Publishing, Oxford, London.

GÜLEÇ, N. 1994. Rb-Sr isotope data from the Ağaçören Granitoid (East of Tuz Gölü): geochronological and 
genetical implications. Turkish Journal of Earth Sciences, 3, 39-43.

GÜRER, Ö. F. \& AldanmaZ, E. 2002. Origin of the Upper Cretaceous-Cenozoic sedimentary basins within the Tauride-Anatolide platform in Turkey. Geological Magazine, 139, 191-197.

Ilbeyli, N., Pearce, J. A., Thirlwall, M. F. \& Mitchell, J. G. 2004. Petrogenesis of collisionrelated plutonics in Central Anatolia, Turkey. Lithos, 72, $163-182$.

Johnson, H. D. \& BALdwin, C. T. 1996. Shallow clastic seas. In: READING, H. G. (ed.) Sedimentary Environments: Process, Facies and Stratigraphy. Blackwell Publishing, Oxford. 232-280.

KAYMAKCI, N. 2000. Tectono-stratigraphical evolution of the Cankiri Basin (Central Anatolia, Turkey). Ph.D Thesis, Geologica Ultraiectina. No. 190, Utrecht University Faculty of Earth Sciences, The Netherlands.

KAYMAKCi, N., White, S. H. \& VAN DiJK, P. M. 2000. Paleostress inversion in a multiphase deformed area: kinematic and structural evolution of the Çankiri Basin (central Turkey), Part 1. In: BozkurT, E., Winchester, J. A. \& PiPer, J. A. D. (eds) Tectonics and Magmatism in Turkey and the Surrounding area. Geological Society, London, Special Publication, 173, 445-473.

KAYMAKCI, N., White, S. H. \& VAN DiJK, P. M. $2003 a$. Kinematic and structural development of the Çankiri Basin (Central Anatolia, Turkey): a paleostress inversion study. Tectonophysics, 364, 85-113.

Kaymakci, N., De Bruijn, H., White, S. H., van DiJK, M., SARAÇ, G. \& UnAY, E. 2001a. Tectonic implications of the Neogene stratigraphy of the Çankiri basin with special reference to the Çandir locality (North-Central Anatolia, Turkey). In: Güleç, E., Begun, D. R. \& GeraAds, D. (eds) Geology and Vertebrate Paleontology of the Miocene hominoid locality of Candir. Courier Forschugsinstitut Senckenberg, 240, 9-28.

KaYMaKci, N., OZÇEliK, Y., White, S. H. \& VAN DiJK, P. M. 2001b. Neogene Tectonics of the Çankiri Basin (north Central Turkey), Turkish Association of Petroleum Geologists Bulletin, 13, 27-56.

Kaymakci, N., Duermeijer, C. E., Langereis, C., White, S. H. \& VAN DiJK, P. M. 2003b. Oroclinal bending due to indentation: a paleomagnetic study for the early Cenozoic evolution of the Çankiri Basin (central Anatolia, Turkey). Geological Magazine. 140, 343-355.

KaZANCI, N. \& VAROL, B. 1990. Development of a mass flow-dominated fan-delta complex and associated carbonate reefs within a transgressive Paleocene succession, Central Anatolia, Turkey. Sedimentary Geology, 68, 261-278.

Ketin, İ. 1966. Anadolu'nun tektonik birlikleri. Maden Tetkik ve Arama Enstitüsü Dergisi, 66, 20-34.

KUşCU, İ. 1997. Mineralogical and geochemical comparison of skarns in the Akdağmadeni, Akçakışla and Keskin districts, Central Anatolia, Turkey. Ph.D. Thesis, Middle East Technical University, Ankara (unpublished).

NORMAN, T. 1972. Ankara doğusunda Yahşihan bölgesinde Üst Kretase-Alt Tersiyer yaşlı arazinin jeolojisi. Maden Tetkik ve Arama Enstitüsü Dergisi, Ankara.
OCAKoĞLU, F. \& ÇINER, A. 1997. Fay denetimli bir havzada sedimanter dolgunun niteligi ve evrimi: Çankırı havzası kuzeyinden Lütesiyen yaşı bir örnek. Hecettepe Üniversitesi Yerbilimleri, 19, 89-108.

OKAY, A. I. 1984. Distribution and characteristics of the northwest Turkish blueschists, In: DIXON, J. E. \& Robertson, A. H. F. (eds), The Geological Evolution of the Eastern Mediterranean, Blackwell Publishing, Oxford, London

OKAY, A. I., TANSEL, İ. \& TÜYÜSZ, O. 2001. Obduction, subduction and collision as reflected in the Upper Cretaceous-Lower Eocene sedimentary record of western Turkey. Geological Magazine, 138, 117-142.

OKAY, A. I., ŞENGÖR, A. M. C. \& GÖRÜR, N. 1994. Kinematic history of the opening of the Black Sea and its effect on the surrounding regions. Geology, 22, 267-270.

Okay, A. I., Satir, M., Maluski, H., Siyako, M., Monie, P., Metzger, R. \& AKYÜZ, S. 1996. Paleo- and Neo-Tethyan events in northwest Turkey: geological and geochronological constraints. In: YIN, A. \& HARRISON, M. (eds) Tectonics of Asia. Cambridge University Press, 420-441.

OKAY, A. I., TÜYSÜZ, O., SATIR, M., ÖZKAN-Altiner, S., Altiner, D., Sherlock, S. \& EREN, R. H. , 2006. Cretaceous and Triassic subduction-accretion, highpressure-low-temperature metamorphism, and continental growth in the Central Pontides, Turkey. Geological Society America Bulletin, 118, 1247-1269.

ORI, G. G. \& FRIEND, P. F. 1984. Sedimentary basins formed and carried piggyback on active thrust sheets. Geology, 12, 475-478.

Postma, G. 1983. Water escape structures in the context of depositional model of a mass-flow dominated conglomeratic fan delta (Abrioja Formation, Pliocene, America basin, SE Spain). Sedimentology, 30, 91-104.

Postma, G. \& RoeP, T. B. 1985. Resedimented conglomerates in the bottom set of a Gilbert-type gravel delta. Journal of Sedimentary Petrology, 55, 874-885.

REAding, H. G. \& Collinson, J. D. 1996. Clastic coasts. In: ReAding, H. G. (ed.) Sedimentary Environments: Process, Facies and Stratigraphy. Blackwell Science, Oxford, 154-231.

RIBA, O. 1976. Syntectonic unconformities of the Alto Cardener, Spanish Pyrenees: a genetic interpretation. Sedimentary Geology, 15, 213-33.

Rice, S. P., Robertson, A. H. F. \& Ustä̈mer, T. 2006. Late Cretaceous-Early Cenozoic tectonic evolution of the Eurasian active margin in the Central and Eastern Pontides, northern Turkey. In: Roberston, A. H. F. \& Mountrakis, D. (eds) Tectonic Development of the Eastern Mediterranean Region. Geological Society, London, Special Publications, 260, 413-445.

RobertSON, A. H. F. 2002. Overview of the genesis and emplacement of Mesozoic ophiolites in the Eastern Mediterranean Tethyan region. Lithos, 65, 1-67.

RoBinson, A. 1997. Introduction: Tectonic elements of the Black Sea region. In: Robinson, A. (ed.), Regional and petroleum geology of the Black Sea and surrounding region. American Association of Petroleum Geologists Memoir, 68, 1-6. 
RoJAY, B. F. 1993. Tectonostratigraphy and neotectonic characteristics of the southern margin of MerzifonSuluova basin (Central Pontides, Amasya). Ph.D. Thesis, METU Geological Engineering Department (Ankara, Turkey), (unpublished.)

Rojay, B. F. 1995. Post-Triassic evolution of central Pontides: Evidence from Amasya region, Northern Anatolia. Geologica Romana, 31, 329-350.

RoJAY, B. F. \& SÜZEN, L. 1997. Tectonostratigraphic evolution of an arc-trench basin on accretionary ophiolitic melange prism, Central Anatolia, Turkey. Turkish Association of Petroleum Geologist Bulletin, 9, 1-12.

Rojay, B., Altiner, D., Özkan Altiner, S., Önen, P., James, S. \& ThiRwall, M. 2004. Geodynamic significance of the Cretaceous pillow basalts from North Anatolian Ophiolitic Mélange Belt (Central Anatolia, Turkey): geochemical and paleontological constrains. Geodinamica Acta, 17, 349-361.

Rojay, B., Yaliniz, K. \& Altiner, D. 2001. Age and origin of some pillow basalts from Ankara melange and their tectonic implications to the evolution of northern branch of Neotethys, Central Anatolia. Turkish Journal of Earth Sciences, 10, 93-102.

SAnVER, M. \& Ponat, E. 1981. Kırşehir ve dolaylarina iliskin paleomagnetik bulgular. Kirsehir Masifinin rotasyonu. İstanbul Yerbilimleri, 2, 2-8.

ŞENGÖR, A. M. C. \& YIlmaZ, Y. 1981. Tethyan evolution of Turkey: a plate tectonic approach. Tectonophysics, 75, 181-241.

SunAL, G. \& TÜYsüZ, O. 2002. Palaeostress analysis of Tertiairy post-collosional structures in the Western Pontides, northern Turkey. Geological Magazine, 139, 343-359.

TÜYSÜZ, O. 1985. Kargı Masifi ve dolayındaki tektonik birliklerin ayırdı ve arasstırllmast (petrolojik inceleme). Istanbul Univ. Jeoloji Mühendisliği Bölümü, Doktora Tezi. (unpublished $\mathrm{PhD}$ Thesis)

TÜYSÜZ, O. 1999. Geology of the Cretaceous sedimentary basins of the Western Pontides, Geological Journal, 34, 75-93.

TÜYSÜZ, O. \& TEKIN, U. K. 2007. Timing of imbrication of an active continental margin facing the northern branch of Neotethys, Karg1 Massif, northern Turkey. Cretaceous Research, 28, 754-764.

Tüysüz, O., Dellaloglu, A. A. \& Terzioglu, N. 1995. A magmatic belt within the Neo-Tethyan suture zone and its role in the tectonic evolution of northern Turkey. Tectonophysics, 243, 173-191.

ÜNALAN, G. 1982. Ankara Güneyindeki Ankara Melanjinin stratigrafisi. In: Proceedings of the Symposium on the Geology of Central Anatolia, Geological Society of Turkey, 35th Annual Meeting, 46-52 [in Turkish with English abstract].

ÜNAY, E. 1994. Early Miocene rodent faunas from eastern Mediterranean area. Part IV. The Gliridae. Proceedings of the Koninklijke Nederlandse Akademie Van Wetenschappen, Amsterdam, B97, 445-490.

Weijers, J. W. H., Schouten, S., Sluijs, A., BRInkhuis, H. \& DAMSTÉ, J. S. S. 2007. Warm arctic continents during the Paleocene-Eocene thermal maximum. Earth and Planetary Science Letters, 261, 230-238.

Whitney, D. L., Teyssier, C., Dilek, Y. \& FAyon, K. 2001. Metamorphism of the Central Anatolian Crystalline Complex, Turkey: influence of orogen-normal collision vs. Wrench-dominated tectonics on P-T-t paths. Journal of Metamorphic Geology, 19, 411-432.

YALINIZ, K. \& GöNCÜOGLU, M. C. 1998. General geological characterictics and distribution of Central Anatolian Ophiolites. Hacettepe University Earth Science Bulletin, 19, 1-15.

YAliniz, M. K., GÖNCÜOĞLU, M. C. \& ÖZKANAltiner, S. 2000. Formation and Emplacement Ages of the SSZ-type Neotethyan Ophiolites in Central Anatolia, Turkey: Paleotectonic Implications. Geological Journal, 35, 53-68.

YAZGAN, E. 1984. Geodynamic Evolution of the eastern Taurus Region (Malatya-Elazığ area, Turkey). In: Geology of Taurus Belt, Proceedings of International Symposium, Mineral Research and Exploration Institute, (MTA, Ankara) Publication, 199-208.

YOLDAŞ, R. 1982. Tosya (Kastamonu) ile Bayat (Çorum) arasındaki bölgenin jeolojisi. Doktora Tezi. Istanbul Universitesi Fen Fakültesi, Genel Jeoloji Kürsüsü, (unpublished). 